Supporting information for:

\title{
Structurally Mapping Alkyl and Amide Basicity in Zincate Chemistry: Diversity in the Synthesis of Mixed Sodium-Zinc Complexes and their Applications in Enolate Formation
}

Pasquale Mastropierro ${ }^{[a]}$, Zoe Livingstone ${ }^{[b]}$, Stuart D. Robertson ${ }^{[b]}$, Alan R.

Kennedy ${ }^{[b]}$ and Eva Hevia ${ }^{[a][b] *}$

\footnotetext{
${ }^{[a]}$ Department für Chemie and Biochemie, Universität Bern, Freiestrasse 3, 3012, Bern, Switzerland.

${ }^{[b]}$ WestCHEM, Department of Pure and Applied Chemistry, University of Strathclyde, 295 Cathedral Street, Glasgow, G1 1XL, UK
} 


\section{Contents}

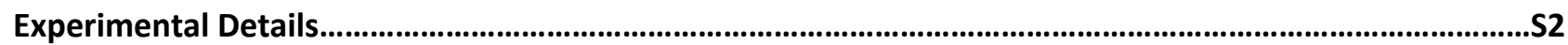

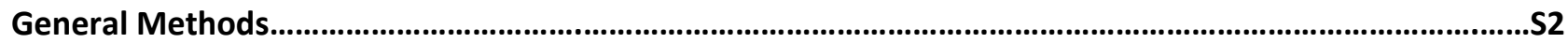

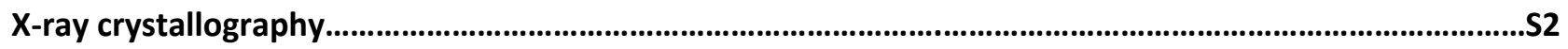

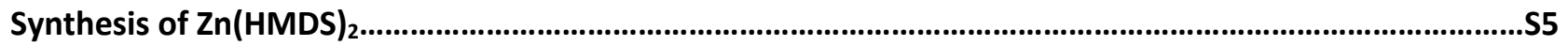

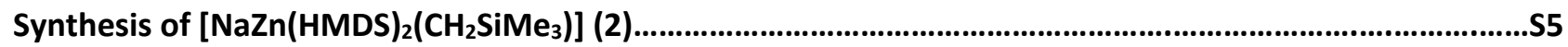

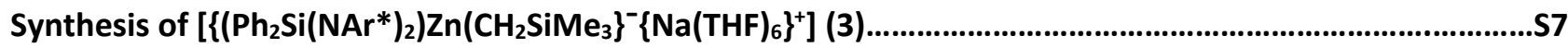

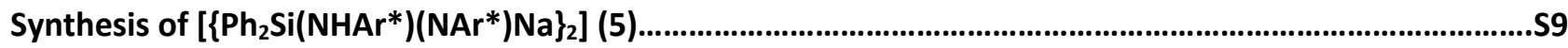

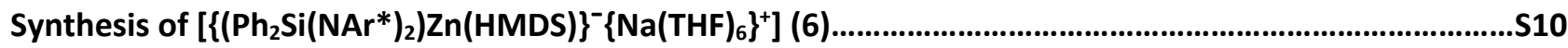

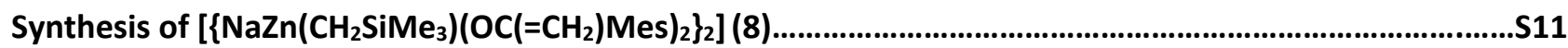

${ }^{1} \mathrm{H}-\mathrm{NMR}$ monitoring of reaction of 3 with variable amounts of $2^{\prime}, 4^{\prime}, 6^{\prime}$ trimethylacetophenone (7).........S13

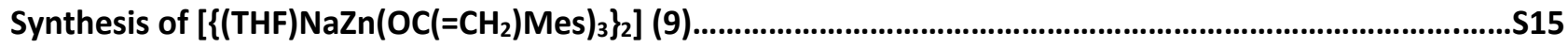

${ }^{1} \mathrm{H}-\mathrm{NMR}$ monitoring of reaction of 6 with variable amount of $2^{\prime}, 4^{\prime}, 6^{\prime}$-trimethylacetophenone (7)...........S17

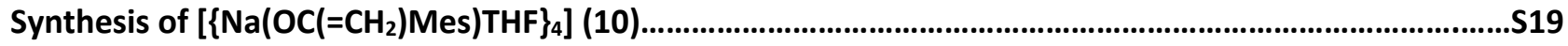

${ }^{1} \mathrm{H}-\mathrm{NMR}$ monitoring of 4 with variable amount of $2^{\prime}, 4^{\prime}, 6^{\prime}$ trimethylacetophenone (7)..............................S20

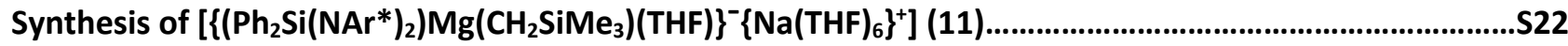

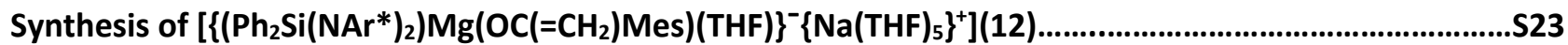

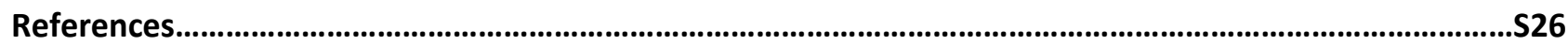




\section{Experimental Details}

\section{General Methods}

All the reactions and manipulation were performed under protective Argon atmosphere; using the standard Schlenck technique or Glovebox MBraun equipped with a gas purification and recirculation unit. Toluene, diethyl ether, hexane and tetrahydrofuran were dried over sodium and benzophenone ketyl and purified by distillation under nitrogen atmosphere. Benzene was distilled over sodium and nitrogen atmosphere, after the collection it was stored over activated $4 \AA$ molecular sieves and argon atmosphere. 2,5 diisopropylaniline (Dipp) and $N-N-N^{\prime}-N^{\prime}$-tetramethylethylendiamine (TMEDA) was purified by distillation over calcium hydride and nitrogen atmosphere, they were stored over activated $4 \AA$ molecular sieves and argon atmosphere. $\mathrm{Ph}_{2} \mathrm{Si}\left(\mathrm{NHAr}^{*}\right)_{2}$ (1), $\mathrm{NaCH}_{2} \mathrm{SiMe}_{3}$, and $\mathrm{Zn}\left(\mathrm{CH}_{2} \mathrm{SiMe}_{3}\right)_{2}, \mathrm{Mg}\left(\mathrm{CH}_{2} \mathrm{SiMe}_{3}\right)_{2}$ were prepared as reported in literature. ${ }^{1,2,3,4}$ Compound 4 was prepared as TMEDA solvate [ $\mathrm{NaZn}\left(\mathrm{CH}_{2} \mathrm{SiMe}_{3}\right)_{3}(\mathrm{TMEDA})_{2}$ ] following the reported synthesis in the literature, ${ }^{5} 2^{\prime}, 4^{\prime}, 6^{\prime}$ trimethylacetophenone (7) was purchased from Sigma-Aldrich and stored over activated $4 \AA \AA$ molecular sieves.

NMR spectra were performed in J. Young's NMR tube, prior oven dried and flushed with Ar. NMR spectra were recordered using a Bruker AV 400 spectrometer operating at $400.13 \mathrm{MHz}$ for ${ }^{1} \mathrm{H}, 100.62 \mathrm{MHz}$ for ${ }^{13} \mathrm{C}\left\{{ }^{1} \mathrm{H}\right\}$ or a Bruker AV 600 spectrometer operating at $600 \mathrm{MHz}$ for ${ }^{1} \mathrm{H}$ and $150 \mathrm{MHz}$ for ${ }^{13} \mathrm{C}\left\{{ }^{1} \mathrm{H}\right\}$ or a Bruker AV 400 spectrometer operating at $300 \mathrm{MHz}$ for ${ }^{1} \mathrm{H}$ and $75 \mathrm{MHz}$ for ${ }^{13} \mathrm{C}\left\{{ }^{1} \mathrm{H}\right\} .{ }^{1} \mathrm{H}$ and ${ }^{13} \mathrm{C}\left\{{ }^{1} \mathrm{H}\right\} \mathrm{NMR}$ spectra were calibrated against the appropriate solvent signal. All the deuterated solvents for NMR were stored over activated $4 \AA$ molecular sieves and Ar atmosphere.

\section{X-Ray Crystallography}

X-ray data of 3, $\mathbf{5}$ and $\mathbf{1 2}$ Crystallographic data were measured at 123(2) K on Oxford Diffraction Gemini S or Xcalibur $E$ instruments ${ }^{6}$ with graphite monochromated Mo $(\lambda=0.71073 \AA)$ or $\mathrm{Cu}(1.54180 \AA)$ radiation. All structures were solved and refined to convergence on $\mathrm{F}^{2}$ using all unique reflections and programs from the SHELX family ${ }^{7,8}$.

A crystal of $\mathbf{6 , 8 , 9}$ or $\mathbf{1 0}$ immersed in parabar oil was mounted at ambient conditions and transferred into the stream of nitrogen ( $100 \mathrm{~K}$ for $\mathbf{6}$ and $\mathbf{9 ;} 173 \mathrm{~K}$ for $\mathbf{8}$ and 10). All measurements were made on a RIGAKU Synergy $\mathrm{S}$ area-detector diffractometer ${ }^{6}$ using mirror optics monochromated Cu Ka radiation $(\lambda=1.54184 \AA$ ). The unit cell constants and an orientation matrix for data collection were obtained from a least-squares refinement of the setting angles of reflections in the range $6.66^{\circ}<2 \theta<154.69^{\circ}$ (for 6 ), $), 5.092^{\circ}<2 \theta<$ $154.666^{\circ}$ (for 8 ) $7.352^{\circ}<2 \theta<155.294^{\circ}$ (for 9 ) and $7.18^{\circ}<2 \theta<154.04^{\circ}$ (for 10). For compound 6 , a total of 5432 frames were collected using $\omega$ scans, with 0.25 second exposure time ( $1 \mathrm{~s}$ for high-angle reflections), a rotation angle of $0.5^{\circ}$ per frame, a crystal-detector distance of $34.0 \mathrm{~mm}$, at $\mathrm{T}=100(2) \mathrm{K}$. For compound 8, a total of 7068 frames were collected using $\omega$ scans, with 0.75 second exposure time $(2 \mathrm{~s}$ for high-angle reflections), a rotation angle of $0.5^{\circ}$ per frame, a crystal-detector distance of $34.0 \mathrm{~mm}$, at $\mathrm{T}=173(2) \mathrm{K}$. For compound 9, a total of 3110 frames were collected using $\omega$ scans, with 0.25 second exposure time $(1 \mathrm{~s}$ for high-angle reflections), a rotation angle of $0.5^{\circ}$ per frame, a crystal-detector distance of $34.0 \mathrm{~mm}$, at $\mathrm{T}=$ 100 (2) K. For compound 10, A total of 3094 frames were collected using $\omega$ scans, with 0.25 second exposure time ( $1 \mathrm{~s}$ for high-angle reflections), a rotation angle of $0.5^{\circ}$ per frame, a crystal-detector distance of 34.0 $\mathrm{mm}$, at $\mathrm{T}=173(2) \mathrm{K}$. 
Data reduction was performed using the CrysAlisPro ${ }^{4}$ program. The intensities were corrected for Lorentz and polarization effects, and an absorption correction based on the multi-scan method using SCALE3 ABSPACK in CrysAlisPro ${ }^{5}$ was applied.

The structures were solved by direct methods using SHELXT ${ }^{7}$, which revealed the positions of all nonhydrogen atoms of the title compound. All non-hydrogen atoms were refined anisotropically. $\mathrm{H}$-atoms were assigned in geometrically calculated positions and refined using a riding model where each $\mathrm{H}$-atom was assigned a fixed isotropic displacement parameter with a value equal to $1.2 \mathrm{Ueq}$ of its parent atom (1.5Ueq for methyl groups).

refinement of the structures was carried out on $F^{2}$ using full-matrix least-squares procedures, which minimized the function $\Sigma w\left(F_{o}{ }^{2}-F_{c}{ }^{2}\right)^{2}$. The weighting scheme was based on counting statistics and included a factor to downweight the intense reflections. All calculations were performed using the SHELXL-2014/ $7^{8}$ program in OLEX2.4

The X-ray crystal structure determination service unit of the Department of Chemistry and Biochemistry of the University of Bern is acknowledged for measuring, solving, refining and summarizing the structures of compounds 6, 8, 9 and 10. The Synergy diffractometer was partially funded by the Swiss National Science Foundation (SNF) within the R'Equip programme (project number 206021_177033).

Selected crystallographic data are presented in Table S1 and full details in cif format can be obtained free of charge from the Cambridge Crystallographic Data Centre via www.ccdc.cam.uk/data_request/cif

Table S1 Crystallographic parameters for compounds 3, 5, 6

\begin{tabular}{|c|c|c|c|}
\hline & 3 & 5 & 6 \\
\hline $\begin{array}{l}\text { CCDC registration } \\
\text { number }\end{array}$ & 1969846 & 1969848 & 2003586 \\
\hline Empirical Formula & $\mathrm{C}_{64} \mathrm{H}_{103} \mathrm{~N}_{2} \mathrm{NaO}_{6} \mathrm{Si}_{2} \mathrm{Zn}$ & $\mathrm{C}_{77.6} \mathrm{H}_{96.4} \mathrm{~N}_{4} \mathrm{Na}_{2} \mathrm{Si}_{2}$ & $\mathrm{C}_{66} \mathrm{H}_{110} \mathrm{~N}_{3} \mathrm{NaO}_{6} \mathrm{Si}_{3} \mathrm{Zn}$ \\
\hline Molecular Mass (g/mol) & 1141.02 & 1187.34 & 1214.19 \\
\hline $\begin{array}{l}\text { Crystal System and space } \\
\text { group }\end{array}$ & Triclinic $(P-1)$ & $\begin{array}{l}\text { Monoclinic } \\
\left(P 2_{1} / c\right)\end{array}$ & Triclinic $(P-1)$ \\
\hline$a(\AA ̊)$ & $18.2402(5)$ & 13.9586(16) & $10.4905(2)$ \\
\hline$b(\AA)$ & $19.2011(5)$ & $15.763(3)$ & $13.4394(3)$ \\
\hline$c(\AA ̊)$ & $38.0207(10)$ & $16.1002(19)$ & $25.3289(5)$ \\
\hline$\alpha\left(^{\circ}\right)$ & $94.531(2)$ & 90.00 & $84.672(2)$ \\
\hline$\beta\left(^{\circ}\right)$ & $93.752(2)$ & 92.495(12) & $80.423(2)$ \\
\hline$\gamma\left(^{\circ}\right)$ & $90.465(2)$ & 90.00 & $81.864(2)$ \\
\hline$V\left(\AA^{3}\right)$ & $13244.8(6)$ & $3539.2(9)$ & 3477.01(13) \\
\hline Z & 8 & 2 & 2 \\
\hline$\lambda(\AA)$ & 1.54184 & 0.71073 & 1.54184 \\
\hline Measured Reflections & 96451 & 15012 & 58879 \\
\hline Unique Reflections & 48896 & 6070 & 14300 \\
\hline$R_{\text {int. }}$ & 0.0850 & 0.0569 & 0.0541 \\
\hline 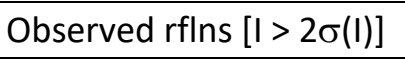 & 30365 & 2873 & 11473 \\
\hline Goof & 1.027 & 0.805 & 1.054 \\
\hline $\mathrm{R}$ [on $\mathrm{F}$, obs rflns only] & 0.0874 & 0.0485 & 0.0456 \\
\hline
\end{tabular}




\begin{tabular}{|l|l|l|l|}
\hline$\omega R$ [on $\mathrm{F}^{2}$, all data] & 0.2589 & 0.1094 & 0.1233 \\
\hline $\begin{array}{l}\text { Largest diff. peak/hole } \\
\left(\mathrm{e} / \AA^{-3}\right)\end{array}$ & $1.41 /-0.72$ & $0.63 /-0.22$ & $0.79 /-0.57$ \\
\hline
\end{tabular}

Table S2 Crystallographic parameters for compounds 8, 9, 10

\begin{tabular}{|c|c|c|c|c|}
\hline & 8 & 9 & 10 & 12 \\
\hline CCDC registration number & 2003584 & 2003587 & 2003585 & 2003583 \\
\hline Empirical Formula & $\begin{array}{l}\mathrm{C}_{60} \mathrm{H}_{90} \mathrm{Na}_{2} \mathrm{O}_{6} \mathrm{Si}_{2} \\
\mathrm{Zn}_{2}\end{array}$ & $\mathrm{C}_{74} \mathrm{H}_{94} \mathrm{Na}_{2} \mathrm{O}_{8} \mathrm{Zn}_{2}$ & $\mathrm{C}_{60} \mathrm{H}_{84} \mathrm{Na}_{4} \mathrm{O}_{8}$ & $\mathrm{C}_{71} \mathrm{H}_{105} \mathrm{MgN}_{2} \mathrm{NaO}_{7} \mathrm{Si}$ \\
\hline Molecular Mass (g/mol) & 1140.21 & 1288.21 & 1025.23 & 1173.95 \\
\hline $\begin{array}{l}\text { Crystal System and space } \\
\text { group }\end{array}$ & Triclinic $(P-1)$ & $\begin{array}{l}\text { Monoclinic } \\
\left(P 2_{1} / n\right)\end{array}$ & $\begin{array}{l}\text { Monoclinic } \\
(P 2 / n)\end{array}$ & Monoclinic $\left(P 2_{1}\right)$ \\
\hline $\mathrm{a}(\AA)$ & $13.4299(2)$ & $14.5110(2)$ & $13.5527(3)$ & $12.3618(3)$ \\
\hline b $(\AA)$ & $17.9855(2)$ & $12.11180(10)$ & $12.3126(4)$ & $15.9028(3)$ \\
\hline$c(\AA)$ & $26.2547(3)$ & $19.9037(2)$ & $18.2475(4)$ & $17.2192(4)$ \\
\hline$\alpha\left(\left(^{\circ}\right)\right.$ & $75.2310(10)$ & 90 & 90 & 90 \\
\hline$\beta\left(^{\circ}\right)$ & $89.1160(10)$ & $93.1170(10)$ & $90.904(2)$ & $91.654(2)$ \\
\hline$\gamma\left(^{\circ}\right)$ & $86.2200(10)$ & 90 & 90 & 90 \\
\hline$V\left(\AA^{3}\right)$ & 6118.79(14) & $3492.99(7)$ & $3044.56(14)$ & $3383.67(13)$ \\
\hline Z & 4 & 2 & 2 & 2 \\
\hline$\lambda(\AA)$ & 1.54184 & 1.54184 & 1.54184 & 0.71073 \\
\hline Measured Reflections & 142804 & 34301 & 30216 & 17680 \\
\hline Unique Reflections & 142804 & 7201 & 6347 & 13526 \\
\hline $\mathrm{R}_{\text {int. }}$ & 0.0526 & 0.0406 & 0.0299 & 0.0201 \\
\hline Observed rflns [I > 2 $\sigma(I)]$ & 111329 & 6134 & 4061 & 8636 \\
\hline Goof & 1.045 & 1.069 & 1.083 & 0.829 \\
\hline $\mathrm{R}$ [on F, obs rflns only] & 0.0628 & 0.0389 & 0.0649 & 0.0417 \\
\hline$\omega \mathrm{R}$ [on $\mathrm{F}^{2}$, all data] & 0.1935 & 0.1055 & 0.2468 & 0.0753 \\
\hline $\begin{array}{l}\text { Largest diff. peak/hole (e/ } \\
\AA^{-3} \text { ) }\end{array}$ & $1.27 /-1.23$ & $0.44 /-0.44$ & $0.38 /-0.20$ & $0.29 /-0.20$ \\
\hline
\end{tabular}




\section{Synthesis of $\mathrm{Zn}(\mathrm{HMDS})_{2}$}

$\mathrm{Zn}(\mathrm{HMDS})_{2}$ was prepared modifying the procedure reported by Hartwig et al. ${ }^{10} 3405 \mathrm{mg}$ of $\mathrm{ZnCl}_{2}(25 \mathrm{mmol})$ and $8360 \mathrm{mg}$ of Li(HMDS) $(50 \mathrm{mmol}$ ) were placed in an Ar flushed and flame dried Schlenk tube. $50 \mathrm{~mL}$ of $\mathrm{Et}_{2} \mathrm{O}$ was added affording a cloudy white suspension. The suspension was allowed to stir for $5 \mathrm{~h} \mathrm{at} 50^{\circ} \mathrm{C}$. After, the suspension was cooled down to room temperature and then the solid was removed by filtration through celite. The light orange solution obtained was concentrated under vacuum affording a light orange suspension. $50 \mathrm{~mL}$ of hexane was then added and the solid was removed by cannula filtration. The resulting colourless solution was concentrated under vacuum affording $\mathrm{ZnHMDS}_{2}$ as colourless oil ( $\left.8300 \mathrm{mg} ; 86 \%\right)$. The spectra are consistence with the reported literature. ${ }^{10}$

\section{Synthesis of $\left[\mathrm{NaZn}(\mathrm{HMDS})_{2}\left(\mathrm{CH}_{2} \mathrm{SiMe}_{3}\right)\right](2)$}

In the reactivity studies compound 2 was prepared in situ. For its characterization, $11 \mathrm{mg}$ of $\mathrm{NaCH}_{2} \mathrm{SiMe}_{3}(0.1$ mmol) were solubilized in $0.5 \mathrm{~mL}$ of D8-THF. $39 \mathrm{mg}$ of freshly prepared $\mathrm{Zn}(\mathrm{HMDS})_{2}(0.1 \mathrm{mmol})$ were added affording a colourless solution. ${ }^{1} \mathrm{H}$ DOSY NMR analysis reveals the co-diffusion of all resonances suggesting that both of the metallic species are part of the same molecular entity in THF solution (diffusion coefficient: $6.256 \mathrm{e}^{-10} \mathrm{~m}^{2} / \mathrm{s}$ )

${ }^{1} \mathrm{H}-\mathrm{NMR}$ (D8-THF; 298K; $300 \mathrm{MHz}$ ) $\delta(\mathrm{ppm}):-0.11$ [s, 16H, CH $3 \mathrm{CHDS}_{8}$ ], -0.2 [s, 9H, $\mathrm{CH}_{3}-\mathrm{CH}_{2} \mathrm{SiMe}_{3}$ ], -1.09 [s, 2H, $\left.\mathrm{CH}_{2}-\mathrm{CH}_{2} \mathrm{SiMe}_{3}\right]{ }^{13} \mathrm{C}\left\{{ }^{1} \mathrm{H}\right\}-\mathrm{NMR}\left(\mathrm{D}_{8}-\mathrm{THF} ; 298 \mathrm{~K} ; 75 \mathrm{MHz}\right) \delta$ (ppm): 6.8 [CH $\left.\mathrm{CH}_{3} \mathrm{HMDS}\right], 4.5\left[\mathrm{CH}_{3}-\mathrm{CH}_{2} \mathrm{SiMe}_{3}\right], 2.8\left[\mathrm{CH}_{2}\right.$ $\left.-\mathrm{CH}_{2} \mathrm{SiMe}_{3}\right]$ 

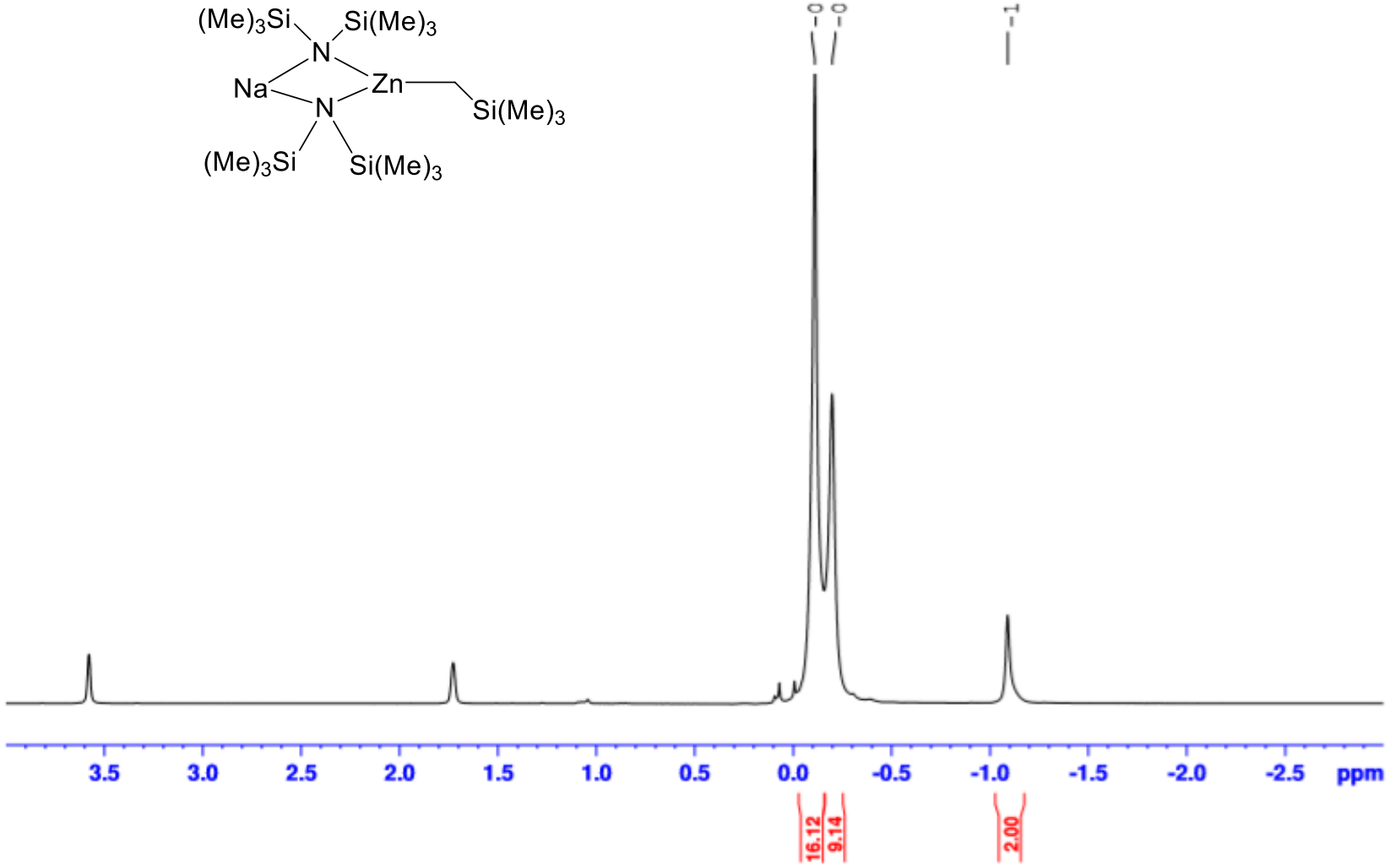

Figure S1: ${ }^{1} \mathrm{H}-\mathrm{NMR}$ spectrum of 2 in $\mathrm{D}_{8}$-THF

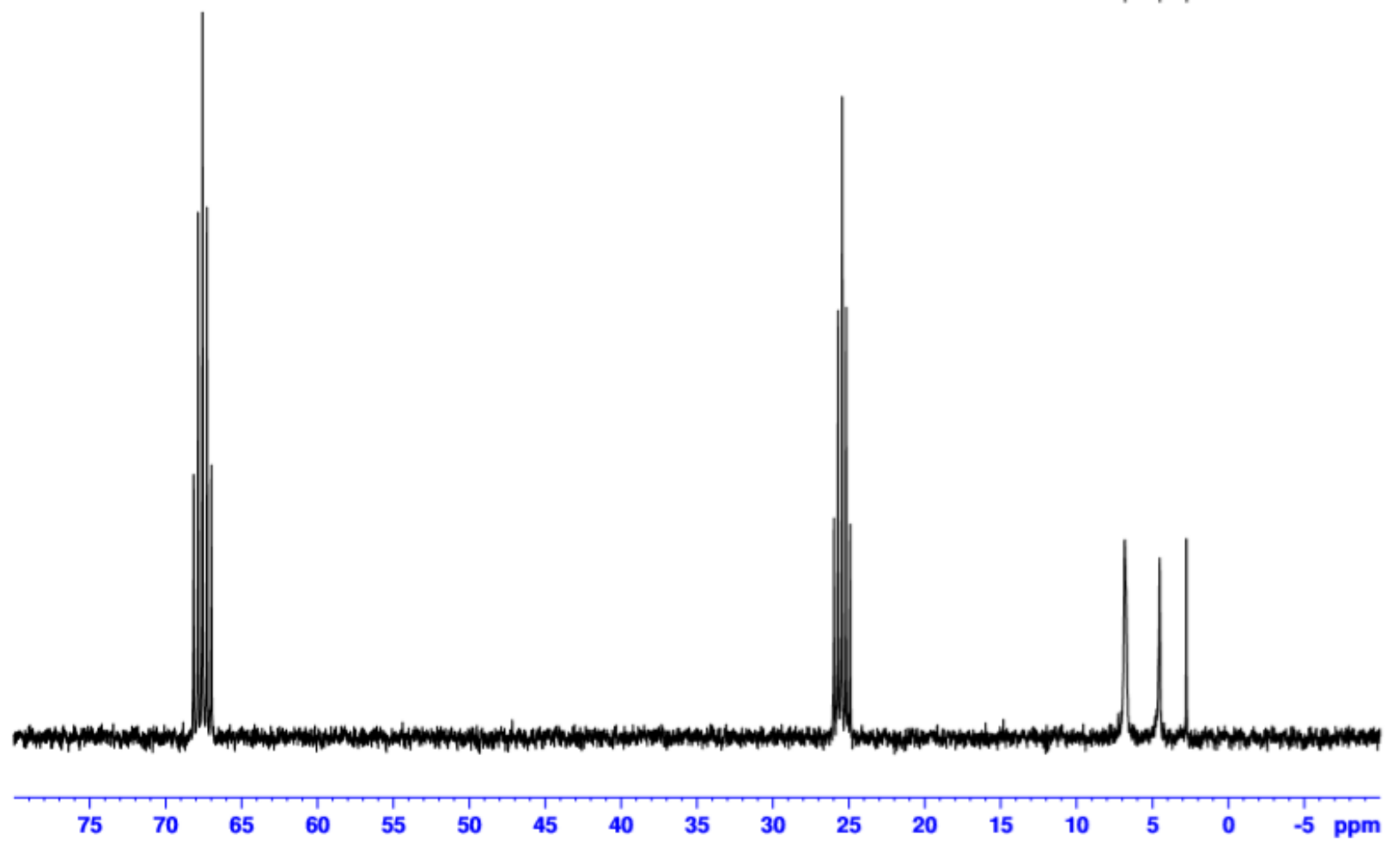

Figure $S 2:{ }^{13} \mathrm{C}\left\{{ }^{1} \mathrm{H}\right\}-\mathrm{NMR}$ spectrum of 2 in $\mathrm{D}_{8}$-THF 


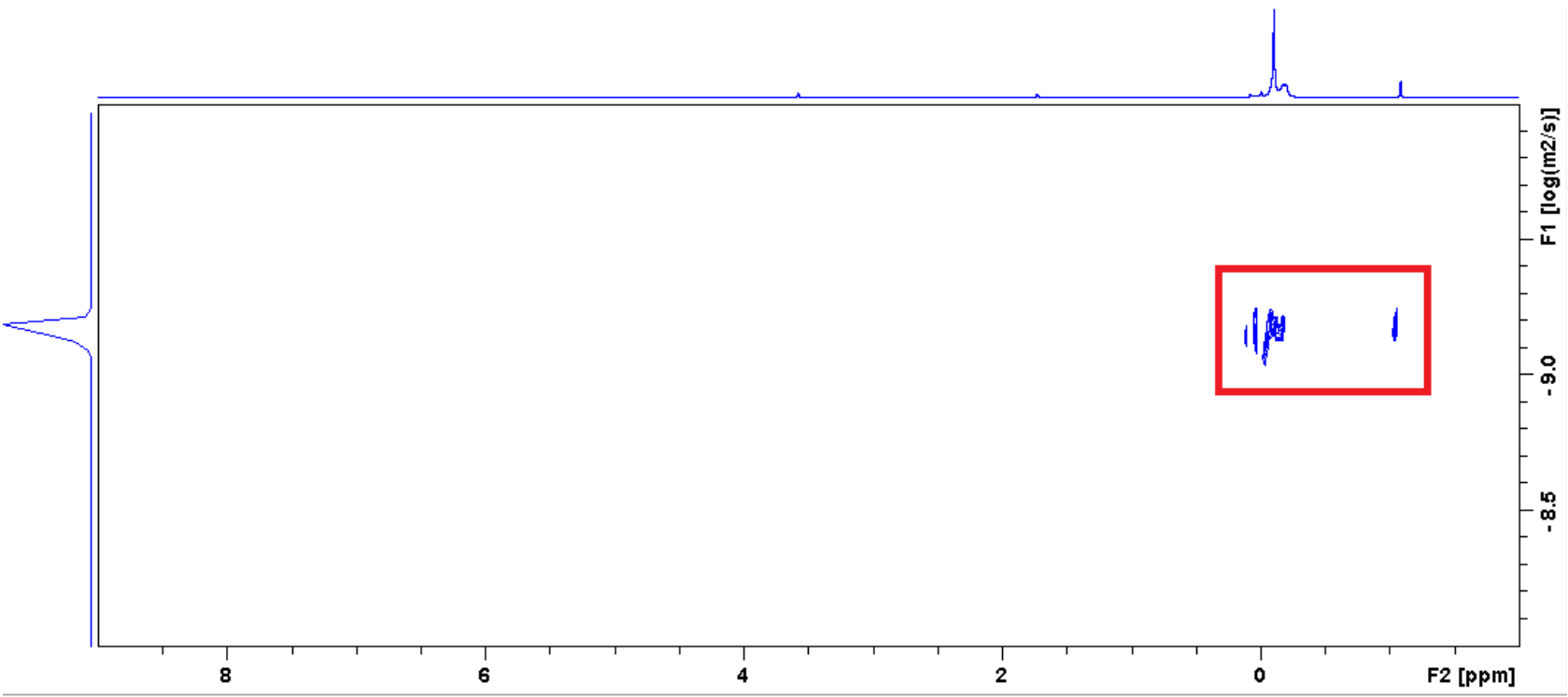

Figure S3: ${ }^{1} \mathrm{H}$ DOSY NMR spectrum of 2 in $\mathrm{D}_{8}$-THF

\section{Synthesis of $\left[\left\{\left(\mathrm{Ph}_{2} \mathrm{Si}\left(\mathrm{NAr}^{*}\right)_{2}\right) \mathrm{Zn}\left(\mathrm{CH}_{2} \mathrm{SiMe}_{3}\right\}^{-}\left\{\mathrm{Na}\left(\mathrm{THF}_{6}\right\}^{+}\right](3)\right.\right.$}

Procedure $\mathrm{A}: \mathrm{Zn}\left(\mathrm{CH}_{2} \mathrm{SiMe}_{3}\right)_{2}(1 \mathrm{mmol})$ was prepared in situ by mixing $136 \mathrm{mg}$ of $\mathrm{ZnCl}_{2}(1 \mathrm{mmol})$ with $\mathrm{LiCH}_{2} \mathrm{Si}(\mathrm{Me})_{3}(2 \mathrm{~mL}$ of a $1 \mathrm{M}$ solution in pentane, $2 \mathrm{mmol})$ in $15 \mathrm{~mL}$ of diethyl ether at $-40^{\circ} \mathrm{C}$. After $1 \mathrm{~h}$ of stirring at room temperature, $\mathrm{LiCl}$ was removing by filtration affording a clear solution to which $1 \mathrm{mmol}$ of $\mathbf{2}$ (556 $\mathrm{mg}$ ) was added. The mixture was allowed to stir at room temperature overnight. Volatiles were removed under vacuum and the white residue was dissolved in $3 \mathrm{~mL}$ of hexane and $1 \mathrm{~mL}$ of THF, affording a paleyellow solution. Overnight storage in a fridge $\left(4^{\circ} \mathrm{C}\right.$ ) furnished colourless crystal of 3 (660 $\mathrm{mg} ; 64 \%$ )

Procedure $B: 386 \mathrm{mg}$ of freshly prepared $\mathrm{Zn}(\mathrm{HMDS})_{2}(1 \mathrm{mmol})$ was solubilized in $3 \mathrm{~mL}$ of hexane. The solution was added via canula to a suspension of $110 \mathrm{mg}$ of $\mathrm{NaCH}_{2} \mathrm{Si}(\mathrm{Me})_{3}$ and $3 \mathrm{~mL}$ of hexane. The suspension was allowed to stir at room temperature overnight. Volatiles were removed under vacuum and to the white residue was dissolved in $3 \mathrm{~mL}$ of hexane and $1 \mathrm{~mL}$ of THF, affording a pale-yellow solution. Overnight storage in a fridge $\left(4^{\circ} \mathrm{C}\right)$ furnished colourless crystal of 3 ( $880 \mathrm{mg} ; 71 \%$ )

Procedure C: $283 \mathrm{mg}$ of $\mathbf{1}(0.53 \mathrm{mmol})$ and $310 \mathrm{mg}$ of $\mathbf{4}(0.53 \mathrm{mmol})$ were solubilized in $5 \mathrm{~mL}$ of THF and the solution was allowed to stir at reflux overnight. Volatiles were removed under vacuum and to the white residue was dissolved in $3 \mathrm{~mL}$ of hexane and $1 \mathrm{~mL}$ of THF, affording a pale-yellow solution Overnight storage in a fridge $\left(-33^{\circ} \mathrm{C}\right)$ furnished colourless crystal of 3 ( $\left.289 \mathrm{mg} ; 63 \%\right)$

${ }^{1} \mathrm{H}-\mathrm{NMR}\left(\mathrm{C}_{6} \mathrm{D}_{6} ; 298 \mathrm{~K} ; 400 \mathrm{MHz}\right) \delta(\mathrm{ppm}): 7.6[\mathrm{~m}, 4 \mathrm{H}, \mathrm{Ph}], 7.16\left[\mathrm{~m}, 4 \mathrm{H}, \mathrm{Ar}^{*}\right], 7.1[\mathrm{~m}, 6 \mathrm{H}, \mathrm{Ph}], 6.95\left[\mathrm{t}, 2 \mathrm{H}, \mathrm{Ar}^{*}\right.$ J=7.57], 4.28 [sept., $4 \mathrm{H}, \mathrm{CH}$ i-Pr, J=6.07Hz], $3.42\left[\mathrm{~m}, 18 \mathrm{H}, \mathrm{O}-\mathrm{CH}_{2} \mathrm{THF}\right], 1.37\left[\mathrm{~m}, 18 \mathrm{H}, \mathrm{CH}_{2} \mathrm{THF}\right], 1.16[\mathrm{~d}, 24 \mathrm{H}$, $\mathrm{CH}_{3} \mathrm{i}-\mathrm{Pr}$ ], $0.18\left[\mathrm{~s}, 9 \mathrm{H}, \mathrm{CH}_{3}\right.$ of $\left.-\mathrm{CH}_{2} \mathrm{SiMe}_{3}\right],-0.7\left[\mathrm{~s}, 2 \mathrm{H}, \mathrm{CH}_{2}\right.$ of $-\mathrm{CH}_{2} \mathrm{SiMe}_{3}$ ] It should be noted that around 2 molecules of the solvating THF present in $\mathbf{3}$ were removed under vacuum when drying the crystals ${ }^{13} \mathrm{C}\left\{{ }^{1} \mathrm{H}\right\}$ NMR $\left(\mathrm{C}_{6} \mathrm{D}_{6} ; 298 \mathrm{~K}, 100 \mathrm{MHz}\right) \delta(\mathrm{ppm}): 151.3,145.0,144.7$ [ $\mathrm{C}_{\text {quaternary }} \mathrm{Ar}^{*}$ and Ph], 135.7, 127.3, 123.9, 119.4 [CH, Ar* and Ph], 68.4 [O- $\mathrm{CH}_{2}$ of THF], 28.6 [CH i-Pr], 26.0 [ $\left.\mathrm{CH}_{2} \mathrm{THF}\right], 25.2\left[\mathrm{CH}_{3} \mathrm{i}-\mathrm{Pr}\right], 3.4\left[\mathrm{CH}_{3},-\mathrm{CH}_{2} \mathrm{SiMe}_{3}\right],-5.2$ $\left[\mathrm{CH}_{2},-\mathrm{CH}_{2} \mathrm{SiMe}_{3}\right]$ Elemental analysis: analytical calculated: $\mathrm{C}_{52} \mathrm{H}_{79} \mathrm{~N}_{2} \mathrm{NaO}_{3} \mathrm{Si}_{2} \mathrm{Zn} \mathrm{C} 67.54, \mathrm{H}$ 8.61, N 3.03. Found: $\mathrm{C} 66.35, \mathrm{H}$ 8.49, N 3.07. When drying crystals under vacuum some of solvating THF was removed. The ${ }^{1} \mathrm{H}-$ NMR, of the batch used for the elemental analysis, shows in the solid there are an average of 3 molecules of THF instead of 6 


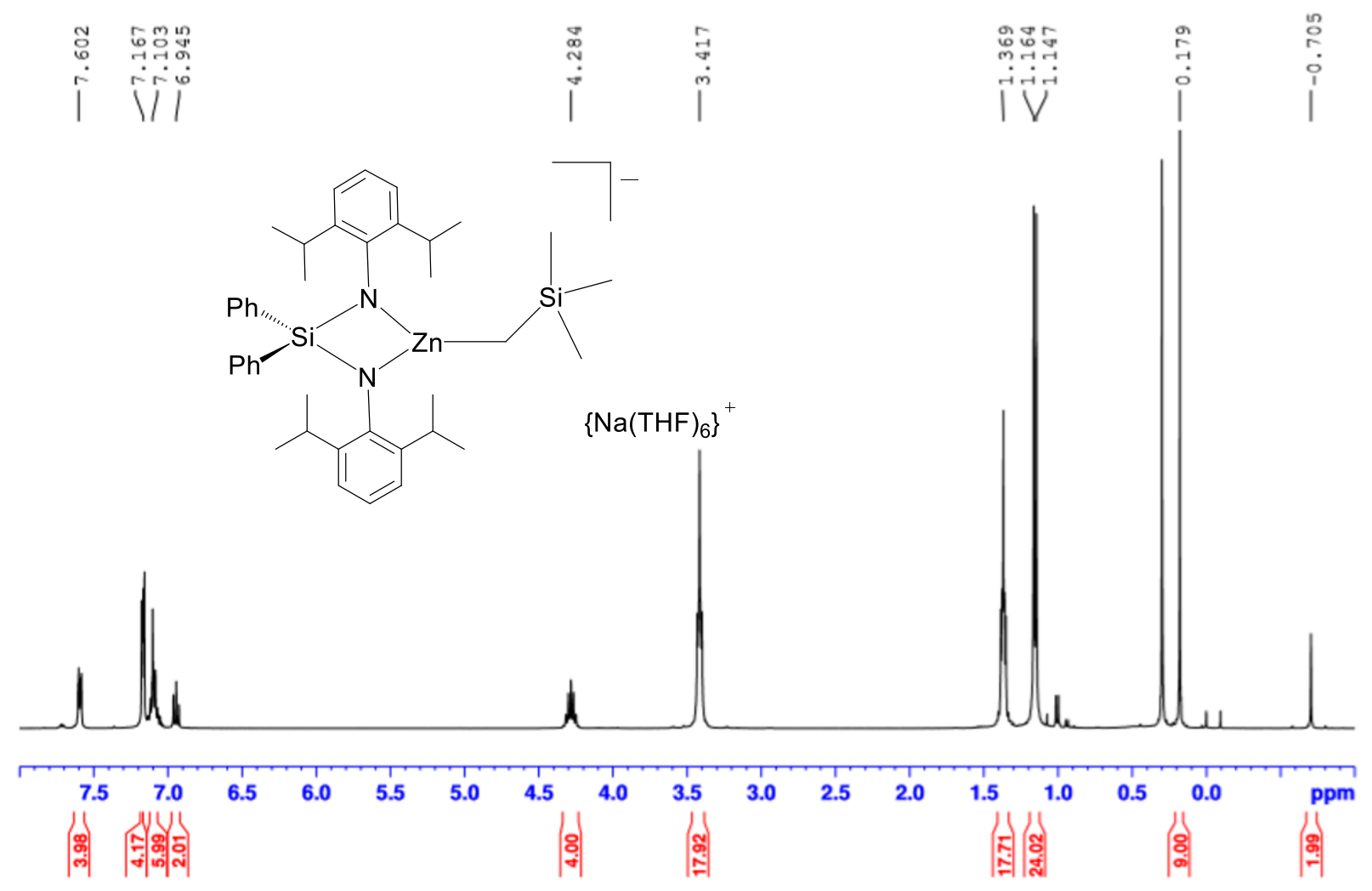

Figure S4: ${ }^{1} \mathrm{H}-\mathrm{NMR}$ spectrum of 3 in $\mathrm{C}_{6} \mathrm{D}_{6}$

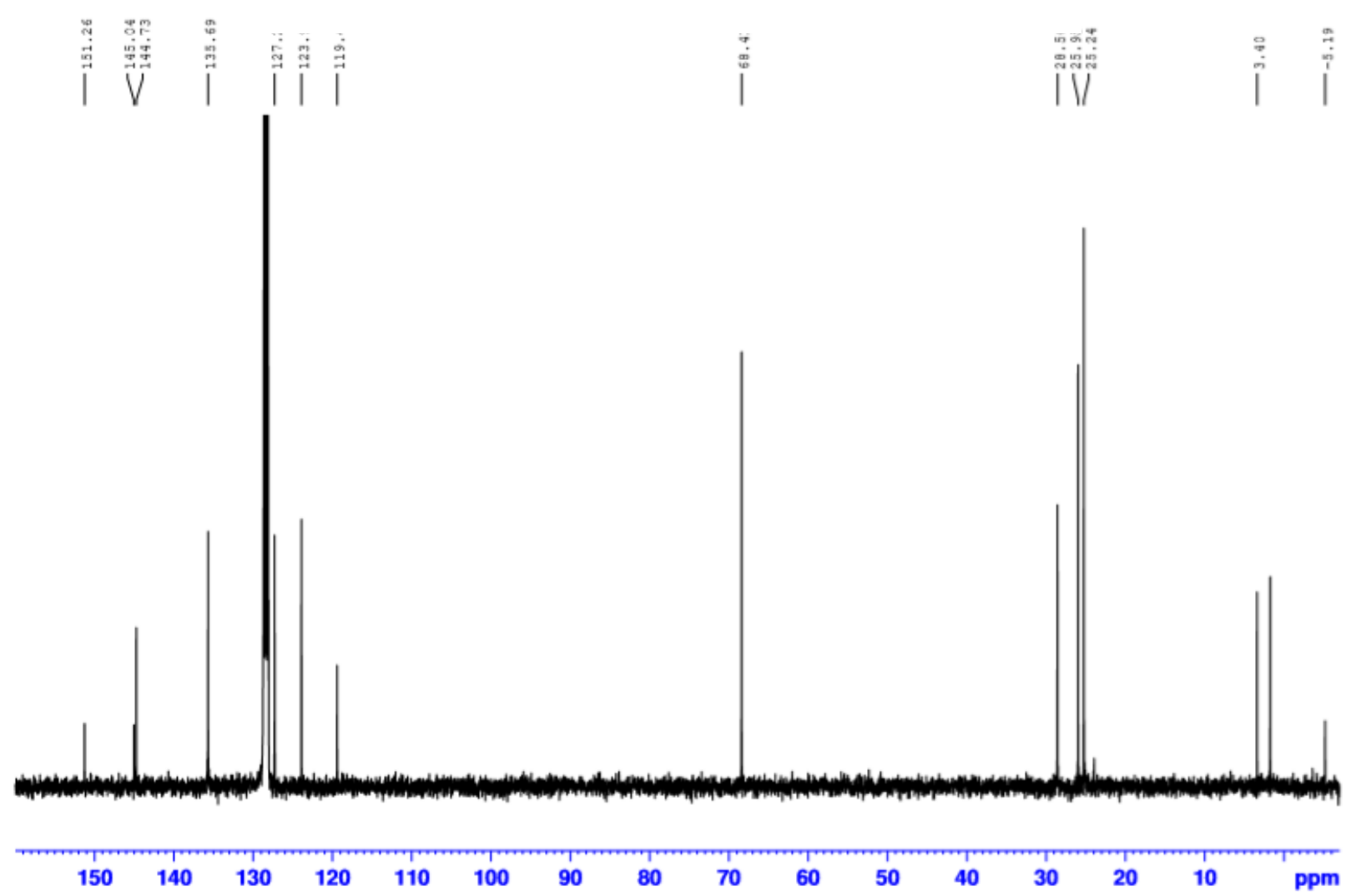

Figure S5: ${ }^{13} C\left\{{ }^{1} H\right\}-N M R$ spectrum of 3 in $C_{6} D_{6}$ 


\section{Synthesis of $\left[\left\{\mathrm{Ph}_{2} \mathrm{Si}\left(\mathrm{NHAr}^{*}\right)\left(\mathrm{NAr}{ }^{*}\right) \mathrm{Na}_{2}\right](5)\right.$}

$\mathrm{NaCH}_{2} \mathrm{SiMe}_{3}(110 \mathrm{mg}, 1 \mathrm{mmol})$ was suspended in a Schlenk tube in $5 \mathrm{~mL}$ of hexane. An equivalent of already prepared $\mathrm{Ph}_{2} \mathrm{Si}_{(}\left(\mathrm{NHAr}^{*}\right)_{2}(\mathbf{1})(530 \mathrm{mg}, 1 \mathrm{mmol}$ ) was added and the suspension was allowed to stir for one hour. Toluene $(5 \mathrm{~mL})$ was introduced affording a clear solution. A batch of colourless crystals was isolated after storage of this solution in the freezer for 2 days (364 mg, 66\%). Despite several attempts due to the extremely air sensitive nature of this compound, no satisfactory elemental analysis could be obtained.

${ }^{1} \mathrm{H}-\mathrm{NMR}\left(\mathrm{C}_{6} \mathrm{D}_{6}, 298 \mathrm{~K}, 400 \mathrm{MHz}\right) \delta(\mathrm{ppm}): 7.58[\mathrm{~m}, 8 \mathrm{H}, \mathrm{Ph}], 7.16[\mathrm{~m}, 13 \mathrm{H}, \mathrm{Ph}$ and toluene], $7.02[\mathrm{~m}, 13 \mathrm{H}$, toluene and $\mathrm{Ar}^{*}$ ] 6.51 [t, 2H, Ar*], 3.99 [s, 2H, NH], 3.78 [m, 4H, CH, i-Pr, NHAr*], 3.24 [m, 4H, CH, i-Pr, NAr*], 2.15 [s, 3H, $\mathrm{CH}_{3}$, toluene], 1.07 [d, 24H, CH, i-Pr, NHAr*], 0.97 [d, 24H, $\left.\left.\mathrm{CH}_{3}, \mathrm{i}-\mathrm{Pr}, \mathrm{NAr}{ }^{*}\right]{ }^{13} \mathrm{C}^{1}{ }^{1} \mathrm{H}\right\}-\mathrm{NMR}\left(\mathrm{C}_{6} \mathrm{D}_{6}, 298 \mathrm{~K}\right.$, $100 \mathrm{MHz}) \delta(\mathrm{ppm}): 154.7,142.5,142.0,141.6,139.6$ [ $\mathrm{C}_{\text {quarternary, }} \mathrm{Ph}$, toluene and $\mathrm{Ar}^{*}$ ], 135.0, 129.2, 128.6, 127.4, 125.5, 123.4, 123.1, 121.9, 113.1 [CH, Ph, toluene and Ar*], 28.8 [CH, i-Pr, NHAr*], 27.1 [CH, i-Pr, NAr*], $23.5\left[\mathrm{CH}_{3}, \mathrm{i}-\mathrm{Pr}, \mathrm{NHAr}^{*}\right], 23.2\left[\mathrm{CH}_{3}, \mathrm{i}-\mathrm{Pr}, \mathrm{NAr}{ }^{*}\right], 21.1\left[\mathrm{CH}_{3}\right.$, toluene] Toluene signals due to co-crystalization of this solvent with.

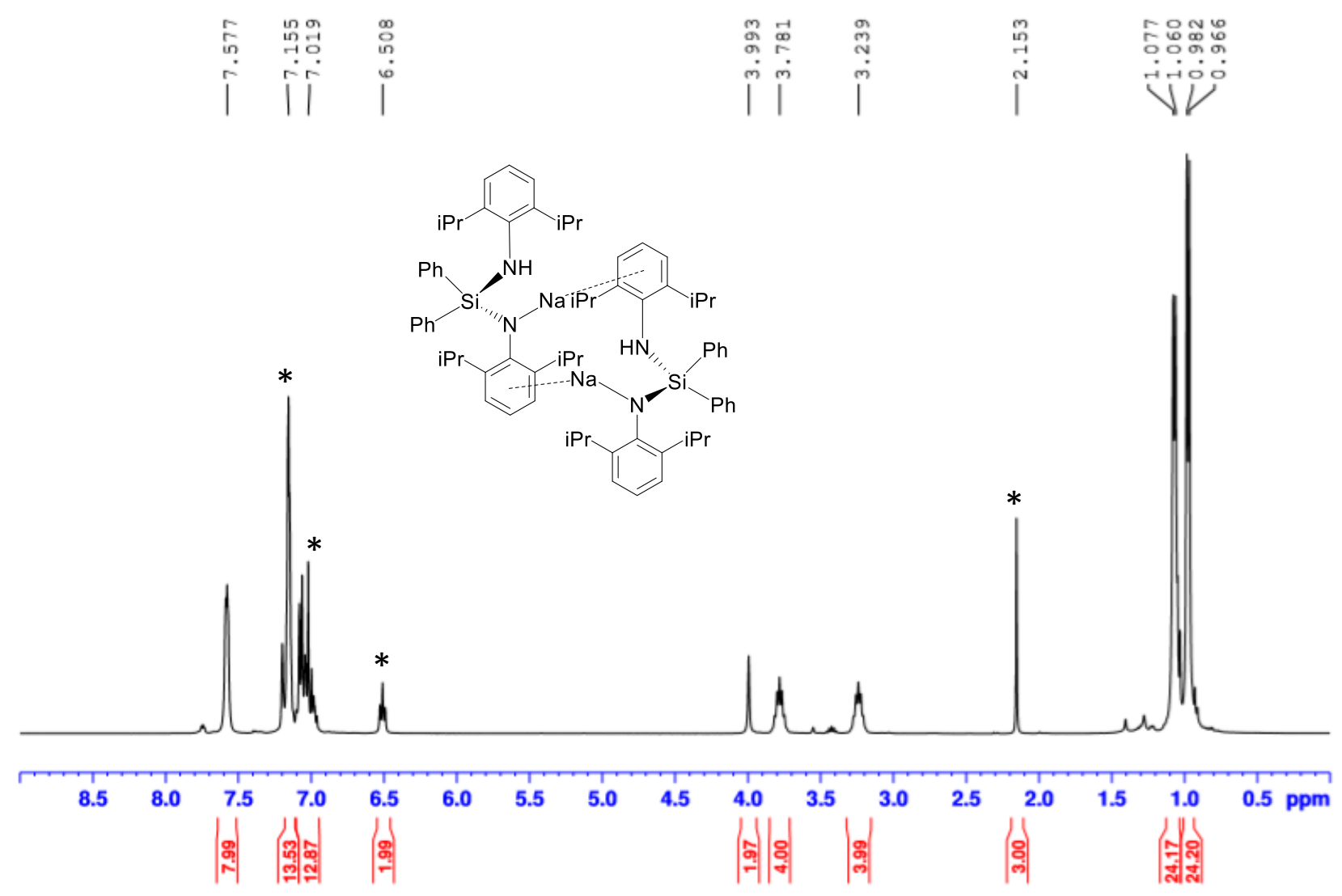

Figure S6: ${ }^{1} \mathrm{H}-\mathrm{NMR}$ spectrum of 5 inC $_{6} \mathrm{D}_{6}\left({ }^{*}\right.$ : resonances of residual toluene of crystallization) 


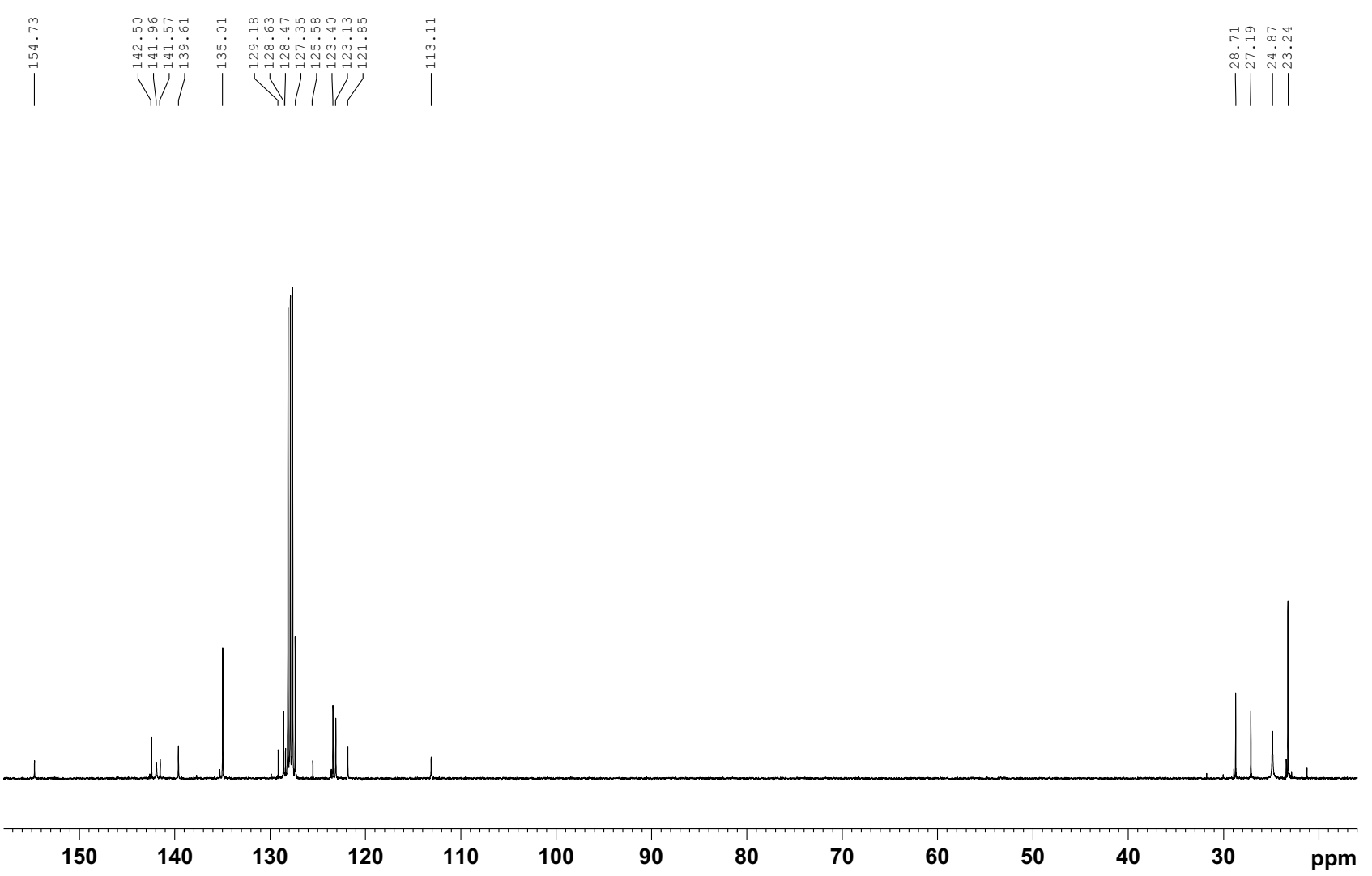

Figure S7: ${ }^{13} \mathrm{C}\left\{{ }^{1} \mathrm{H}\right\}-\mathrm{NMR}$ spectrum of 5 in $\mathrm{C}_{6} \mathrm{D}_{6}$

\section{Synthesis of $\left[\left\{\left(\mathrm{Ph}_{2} \mathrm{Si}\left(\mathrm{NAr}^{*}\right)_{2}\right) \mathrm{Zn}(\mathrm{HMDS})\right\}^{-}\left\{\mathrm{Na}\left(\mathrm{THF}_{6}\right\}^{+}\right](6)\right.$}

$643.3 \mathrm{mg}$ of freshly prepared $\mathrm{Zn}(\mathrm{HMDS})_{2}(1.67 \mathrm{mmol})$ was solubilized in $5 \mathrm{~mL}$ of THF . The solution was added via cannula to $920 \mathrm{mg}$ of $\mathbf{2}(1.67 \mathrm{mmol})$. The mixture was allowed to stir at reflux overnight. Volatiles were removed under vacuum and the white residue was dissolved in $5 \mathrm{~mL}$ of hexane and $1.6 \mathrm{~mL}$ of THF, affording a pale-yellow solution. Overnight storage in a freezer $\left(-33^{\circ} \mathrm{C}\right.$ ) furnished colourless crystals of 6 (1250 $\mathrm{mg}$; $80 \%)$.

${ }^{1} \mathrm{H}-\mathrm{NMR}\left(\mathrm{D}_{8}\right.$-THF; 298K; $300 \mathrm{MHz}$ ) $\delta(\mathrm{ppm}): 7.4[\mathrm{~m}, 4 \mathrm{H}, \mathrm{Ph}], 6.96[\mathrm{~m}, 6 \mathrm{H}, \mathrm{Ph}], 6.71[\mathrm{~d}, 4 \mathrm{H}, \mathrm{Ar} * \mathrm{~J}=7.5 \mathrm{~Hz}], 6.45$ [t, 2H, Ar* J=7.5 Hz], 4.06 [sept., 4H, CH i-Pr], $3.62\left[\mathrm{~m}, 6 \mathrm{H}, \mathrm{O}-\mathrm{CH}_{2} \mathrm{THF}\right.$ ], 1.77 [m, 6H, CH $2 \mathrm{THF}$ ], 0.8 [d, 24H, $\mathrm{CH}_{3} \mathrm{i}-\mathrm{Pr}$ ], $-0.16\left[\mathrm{~s}, 18 \mathrm{H}, \mathrm{CH}_{3} \mathrm{HMDS}\right.$ ]. It should be noted that around 5 molecules of the solvating THF present in 6 were removed under vacuum when drying the crystals. ${ }^{13} \mathrm{C}\left\{{ }^{1} \mathrm{H}\right\}-\mathrm{NMR}$ ( $\mathrm{D}_{8}$-THF; 298K; $\left.75 \mathrm{MHz}\right) \delta$ (ppm): 152.1, 146.5, 144.6 [ $\mathrm{C}_{\text {quaternary }} \mathrm{Ar} *$ and $\mathrm{Ph}$ ], 136.2, 122.2, 117.4 [CH, Ar* and Ph], 68.0 [O- $\mathrm{CH}_{2}$ of THF], 27.9 [CH i-Pr], $26.2\left[\mathrm{CH}_{2} \mathrm{THF}\right], 24.9\left[\mathrm{CH}_{3} \mathrm{i}-\mathrm{Pr}\right], 5.8\left[\mathrm{CH}_{3}, \mathrm{HMDS}\right]$ Elemental analysis: analytical calculated: $\mathrm{C}_{104} \mathrm{H}_{164} \mathrm{~N}_{6} \mathrm{Na}_{2} \mathrm{O}_{5} \mathrm{Si}_{6} \mathrm{Zn}_{2} \mathrm{C}$ 64.93, H 8.53, N 4.50. Found: C 64.93, H 8.59, N 4.37. When drying crystals under vacuum some of solvating THF was removed. The ${ }^{1} \mathrm{H}-\mathrm{NMR}$, of the batch used for the elemental analysis, shows in the solid there are an average of 2.5 molecules of THF instead of 6. 


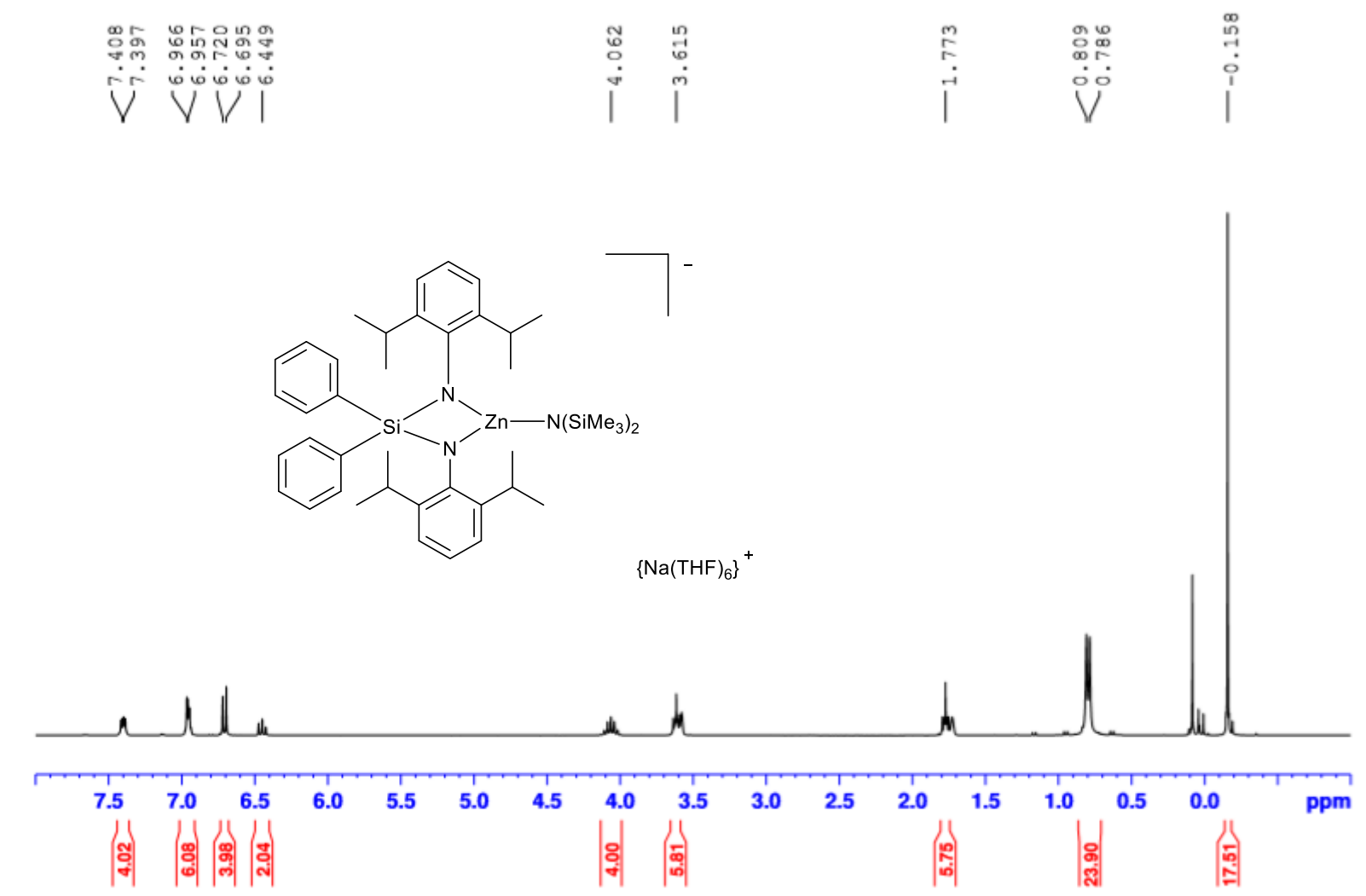

Figure S8: ${ }^{1} \mathrm{H}-\mathrm{NMR}$ spectrum of 6 in $\mathrm{D}_{8}$-THF

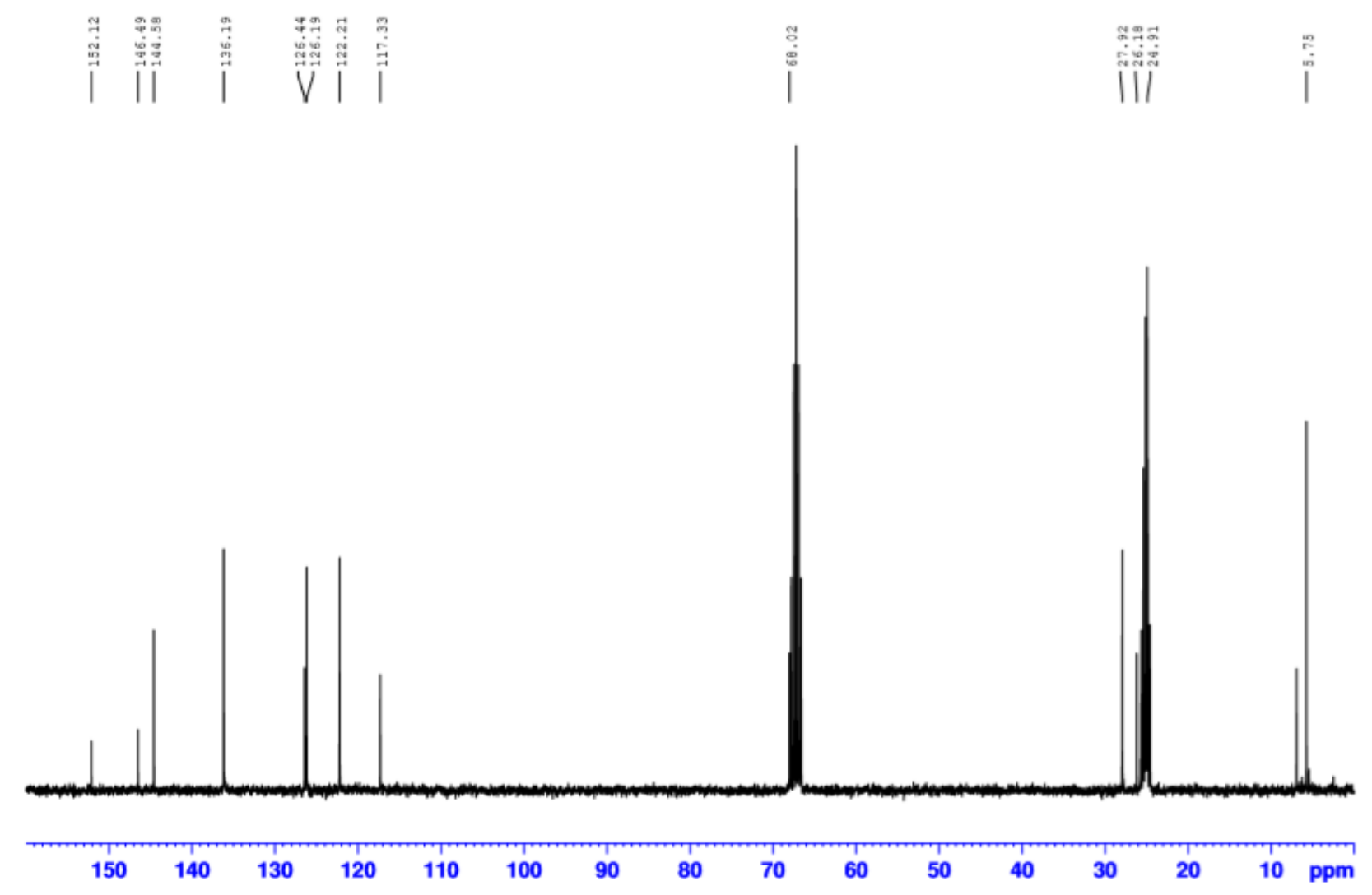

Figure S9: ${ }^{13} \mathrm{C}\left\{{ }^{1} \mathrm{H}\right\}-\mathrm{NMR}$ spectrum of 6 in $\mathrm{D}_{8}$-THF 


\section{Synthesis of $\left[\left\{\mathrm{NaZn}\left(\mathrm{CH}_{2} \mathrm{SiMe}_{3}\right)\left(\mathrm{OC}\left(=\mathrm{CH}_{2}\right) \mathrm{Mes}\right)_{2}\right\}_{2}\right](8)$}

$0.33 \mathrm{~mL}$ ( $2 \mathrm{mmol})$ of 7 were added to a solution of $2100 \mathrm{mg}$ of $5(2 \mathrm{mmol})$ and $5 \mathrm{~mL}$ of THF, in that instant colour change of the solution is observed, from colourless to light yellow. After stirring the reaction mixture at room temperature for $1 \mathrm{~h}$ volatiles were removed under vacuum, and the solid residue was dissolved in warm Toluene $(2 \mathrm{~mL})$. Colourless crystals of 8 were obtained after slowing cooling down the solution. $(697 \mathrm{mg}$ yield: 60\%) When the reaction was monitored by ${ }^{1} \mathrm{H}-\mathrm{NMR}$ quantitative conversion of $\mathbf{3}$ into $\mathbf{8}$ was observed (see Figure S13).

${ }^{1} \mathrm{H}-\mathrm{NMR}$ (D8-THF; 298K; $300 \mathrm{MHz}$ ) $\delta$ (ppm): 6.69 [s, 8H, Mes], 4.09 [s, 4H, =CHH'], $3.34\left[\mathrm{~s}, 4 \mathrm{H},=\mathrm{CH} H^{\prime}\right], 3.61$ [m, 8H, OCH 2 THF], $2.32[\mathrm{~s}, 24 \mathrm{H}, \mathrm{Me}, \mathrm{Mes}] 2.16[\mathrm{~s}, 12 \mathrm{H}, \mathrm{Me}, \mathrm{Mes}], 1.78\left[\mathrm{~m}, 8 \mathrm{H}, \mathrm{CH}_{2} \mathrm{THF}\right] 0.03\left[\mathrm{~s}, 18 \mathrm{H}, \mathrm{CH}_{3}-\right.$ $\mathrm{CH}_{2} \mathrm{SiMe}_{3}$ ], -0.87 [s, 4H, CH$\left.-\mathrm{CH}_{2} \mathrm{SiMe}_{3}\right]{ }^{13} \mathrm{C}\left\{{ }^{1} \mathrm{H}\right\}-\mathrm{NMR}$ (D $-\mathrm{THF} ; 298 \mathrm{~K} ; 5 \mathrm{MHz}$ ) $\delta$ (ppm): 165.9 [C-O], 143.8, 135.5, 135.3 [ $\mathrm{C}_{\text {quaternary }} \mathrm{Mes}$ ], 128.4 [CH Mes], 83.2 [CO=CHH'], 21.2, $20.6\left[\mathrm{CH}_{3} \mathrm{Mes}\right], 3.9\left[\mathrm{CH}_{3} \mathrm{CH}_{2} \mathrm{SiMe}_{3}\right]-7.8$ $\left[\mathrm{CH}_{2} \mathrm{CH}_{2} \mathrm{SiMe}_{3}\right.$ ] Elemental analysis: analytical calculated: $\mathrm{C}_{60} \mathrm{H}_{90} \mathrm{Na}_{2} \mathrm{O}_{6} \mathrm{Si}_{2} \mathrm{Zn}_{2} \mathrm{C} 63.20 \mathrm{H}$ 7.96. Found: $\mathrm{C} 66.32$, $\mathrm{H}$ 8.01. Despite numerous attempts fully satisfactory Elemental analysis for $\mathrm{C}$ could not be obtained which is probably due to air- and moisture-sensitive nature of 8

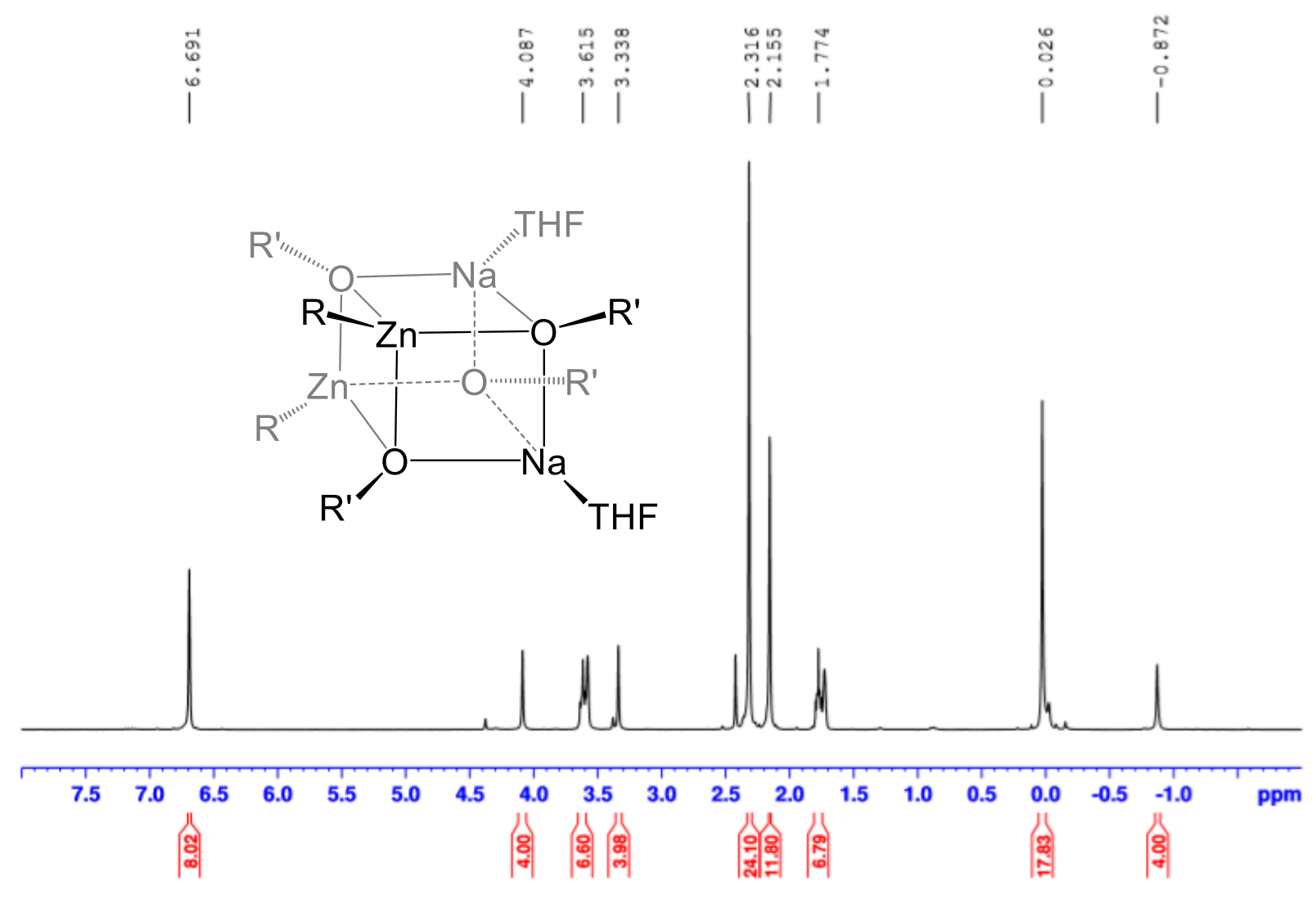

Figure S10: ${ }^{1} \mathrm{H}-\mathrm{NMR}$ spectrum of 8 in $\mathrm{D}_{8}$-THF 


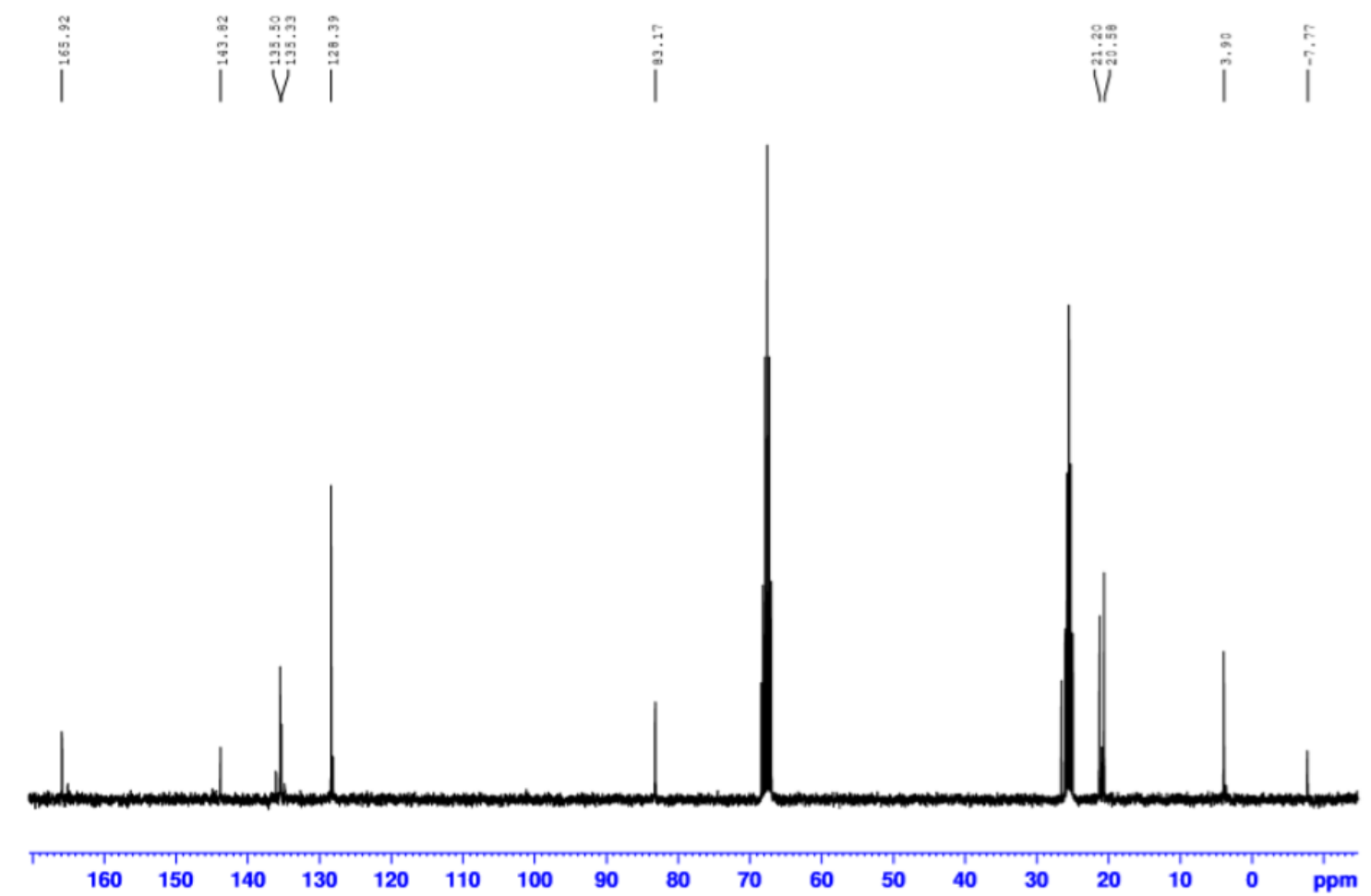

Figure S11: ${ }^{13} \mathrm{C}\left\{{ }^{1} \mathrm{H}\right\}$-NMR spectrum of 8 in $\mathrm{D}_{8}$-THF

${ }^{1} \mathrm{H}-\mathrm{NMR}$ monitoring of reaction of 3 with variable amounts of $2^{\prime}, 4^{\prime}, 6^{\prime}$ trimethylacetophenone (7)

When 3 (100 mg, $0.1 \mathrm{mmol}$ ) was reacted with three equivalents of 7 (48 $\mu \mathrm{L}, 0.3 \mathrm{mmol}$ ), compound 8 was detected in the same yield as seen in the reaction with 2 equivalents, but the additional equivalent of 7 was detected in the reaction mixture (see figure S14). Alternative if the reaction is carried out using just one equivalent of ketone ( $16 \mu \mathrm{L}, 0.1 \mathrm{mmol}$ ), the yield for 8 diminished to $50 \%$ and the unreacted zincate 3 is observed in solution (figure S12).

Signals for $\mathbf{1}\left({ }^{*}\right)$, signals for $\mathbf{3}\left({ }^{*}\right)$, signals for $\mathbf{8}\left({ }^{*}\right)$, signal for hexamethylbenzene $\left({ }^{*}\right)$, signals for $\mathbf{7}\left({ }^{*}\right)$ 


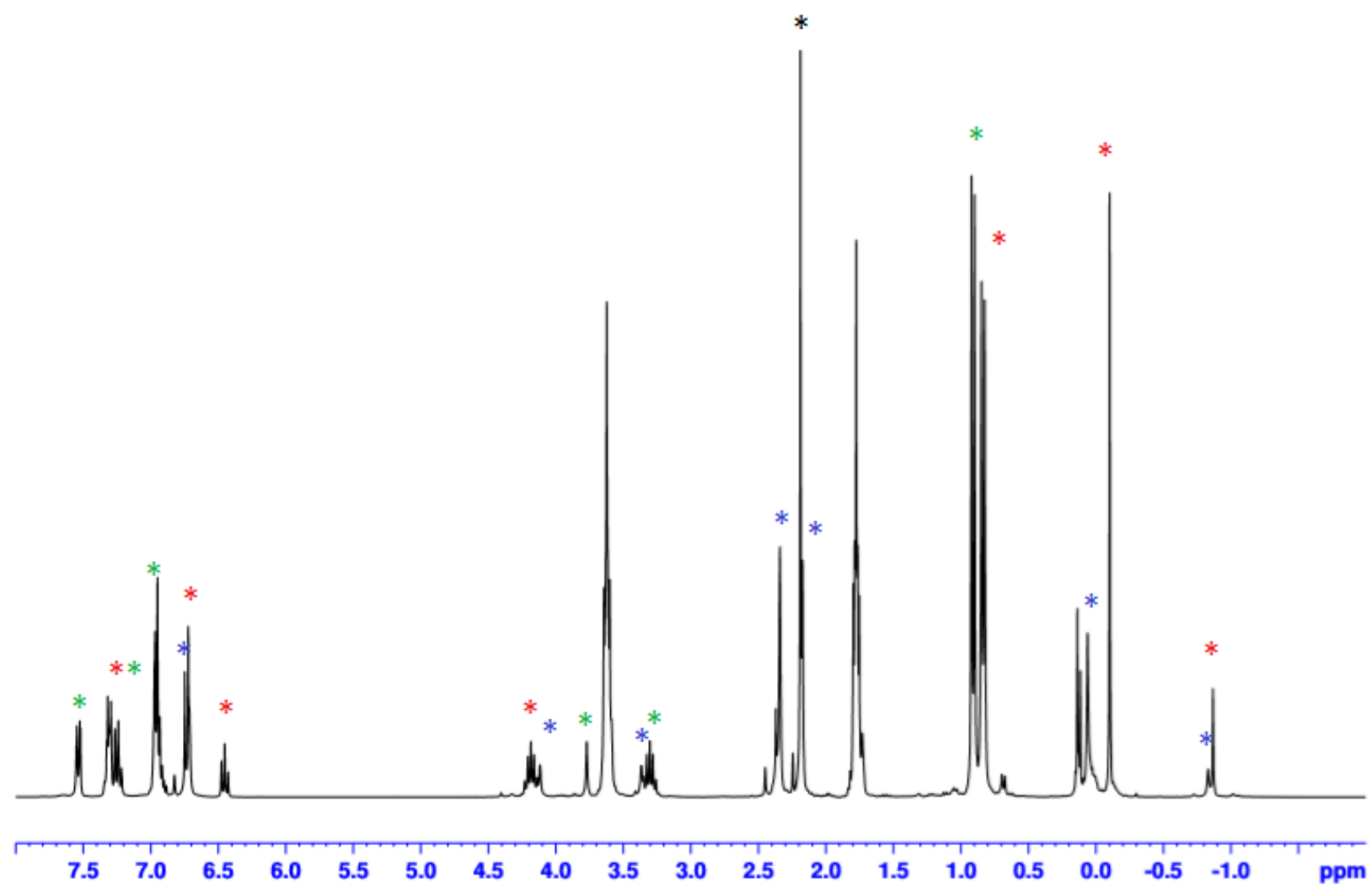

Figure S12: ${ }^{1} \mathrm{H}-\mathrm{NMR}$ spectrum in $\mathrm{D}_{8}$-THF of 3 with 1eq. of 7, after 5 min.

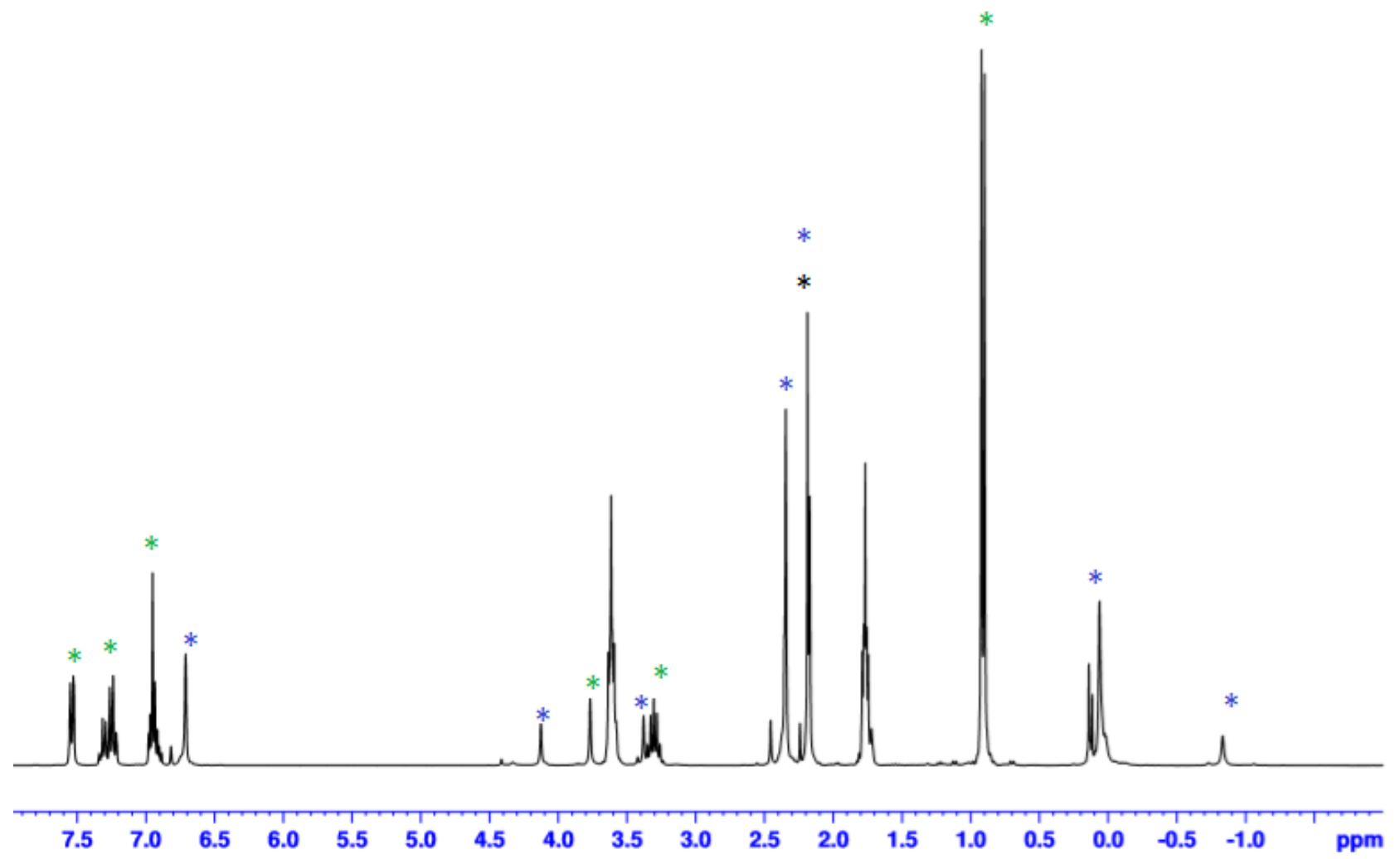

Figure S13: ${ }^{1} \mathrm{H}-\mathrm{NMR}$ spectrum in $\mathrm{D}_{8}$-THF of 3 with 2eq. of 7, after 5 min. 


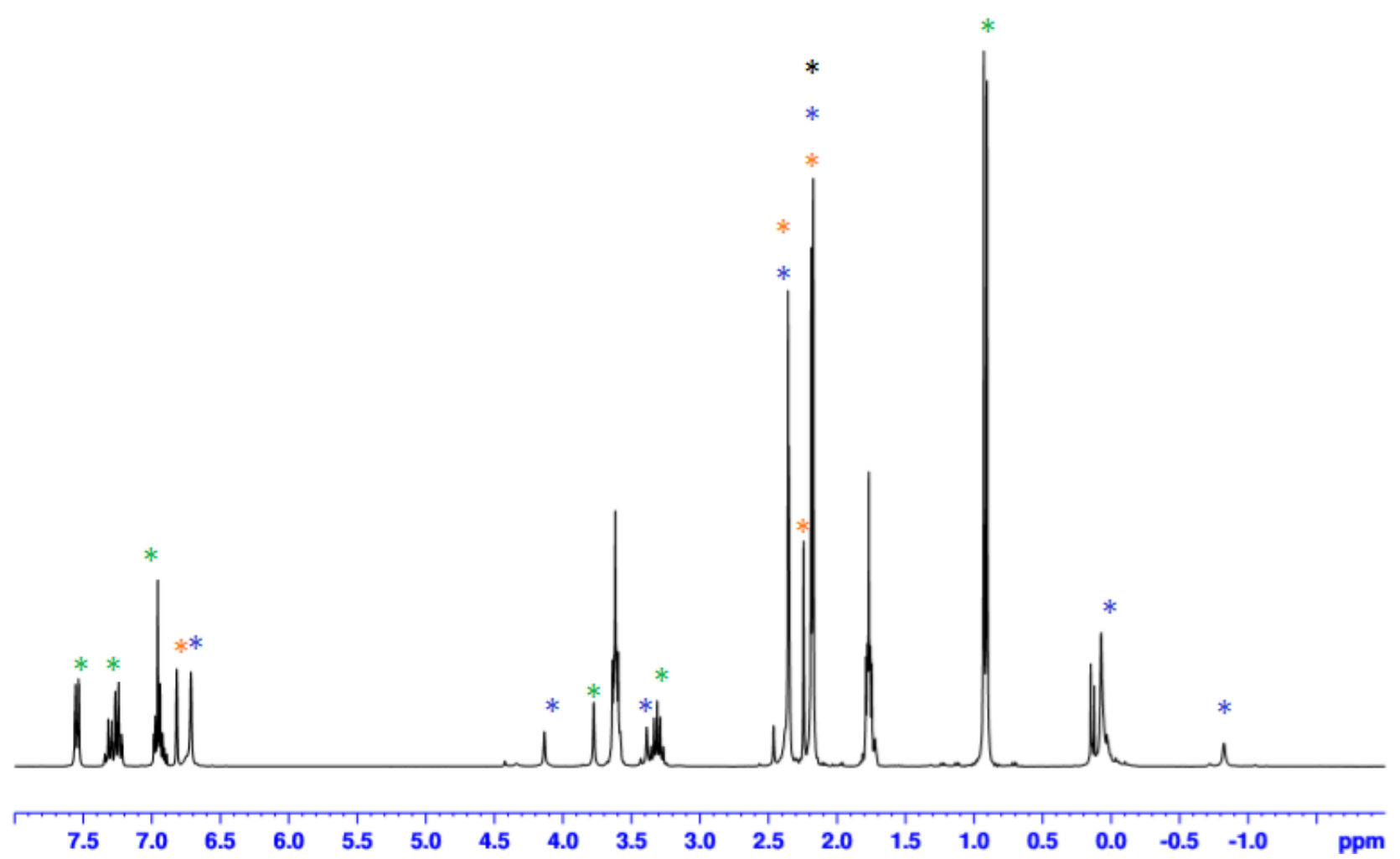

Figure S14: ${ }^{1} \mathrm{H}-\mathrm{NMR}$ spectrum in $\mathrm{D}_{\mathbf{8}^{-}}$-THF of 3 with 3eq. of 7, after $5 \mathrm{~min}$.

\section{Synthesis of $\left[\left\{(\mathrm{THF}) \mathrm{NaZn}\left(\mathrm{OC}\left(=\mathrm{CH}_{2}\right) \mathrm{Mes}\right)_{3}\right\}_{2}\right](9)$}

$938 \mathrm{mg}$ of $6(1 \mathrm{mmol})$ were solubilised in $5 \mathrm{~mL}$ of THF, then $0.5 \mathrm{~mL}$ of 7 ( $3 \mathrm{mmol})$ were added to the solution. The mixture was allowed to stir for $1 \mathrm{~h}$ at $69^{\circ} \mathrm{C}$. The solution was cooled down to room temperature. All the volatiles were removed under vacuum and to the white residue $2 \mathrm{~mL}$ of toluene were added, affording an orange suspension. In order to facilitate the crystallization one additional equivalent of $\mathbf{7}(0.17 \mathrm{~mL})$ were added. The mixture was heated under reflux in an oil bath and let slowly cool down at room temperature for a night furnished colourless crystal of 9 (228 mg yield: $39 \%$ ). When the reaction was monitored by ${ }^{1} \mathrm{H}-\mathrm{NMR}$ quantitative conversion of $\mathbf{6}$ into $\mathbf{9}$ was observed (see figure S18). Despite several attempts due to the extremely air sensitive nature of this compound, no satisfactory elemental analysis could be obtained.

${ }^{1} \mathrm{H}-\mathrm{NMR}\left(\mathrm{D}_{8}\right.$-THF; 298K; $\left.300 \mathrm{MHz}\right) \delta(\mathrm{ppm}): 6.69[\mathrm{~s}, 4 \mathrm{H}, \mathrm{Mes}], 4.38\left[\mathrm{~s}, 2 \mathrm{H},=\mathrm{CHH}\right.$ ], $3.62\left[\mathrm{~m}, 3 \mathrm{H}, \mathrm{OCH}_{2} \mathrm{THF}\right.$ ), $\left.3.38\left[\mathrm{~s}, 2 \mathrm{H},=\mathrm{CH} H^{\prime}\right], 2.17[\mathrm{~s}, 12 \mathrm{H}, \mathrm{Me}, \mathrm{Mes}] 2.17[\mathrm{~s}, 6 \mathrm{H}, \mathrm{Me}, \mathrm{Mes}], 1.77\left[\mathrm{~m}, 3 \mathrm{H}, \mathrm{CH}_{2} \mathrm{THF}\right] .{ }^{13} \mathrm{C}^{1}{ }^{1} \mathrm{H}\right\}-\mathrm{NMR}\left(\mathrm{D}_{8}-\right.$ THF; 298K; $75 \mathrm{MHz}) \delta$ (ppm): 165.1 [C-O], 144.3, 136.1, 134.9 [C quaternary Mes], 128.1 [CH Mes], 83.3 [CO=CHH'], $20.9\left[\mathrm{CH}_{3} \mathrm{Mes}\right]$. 


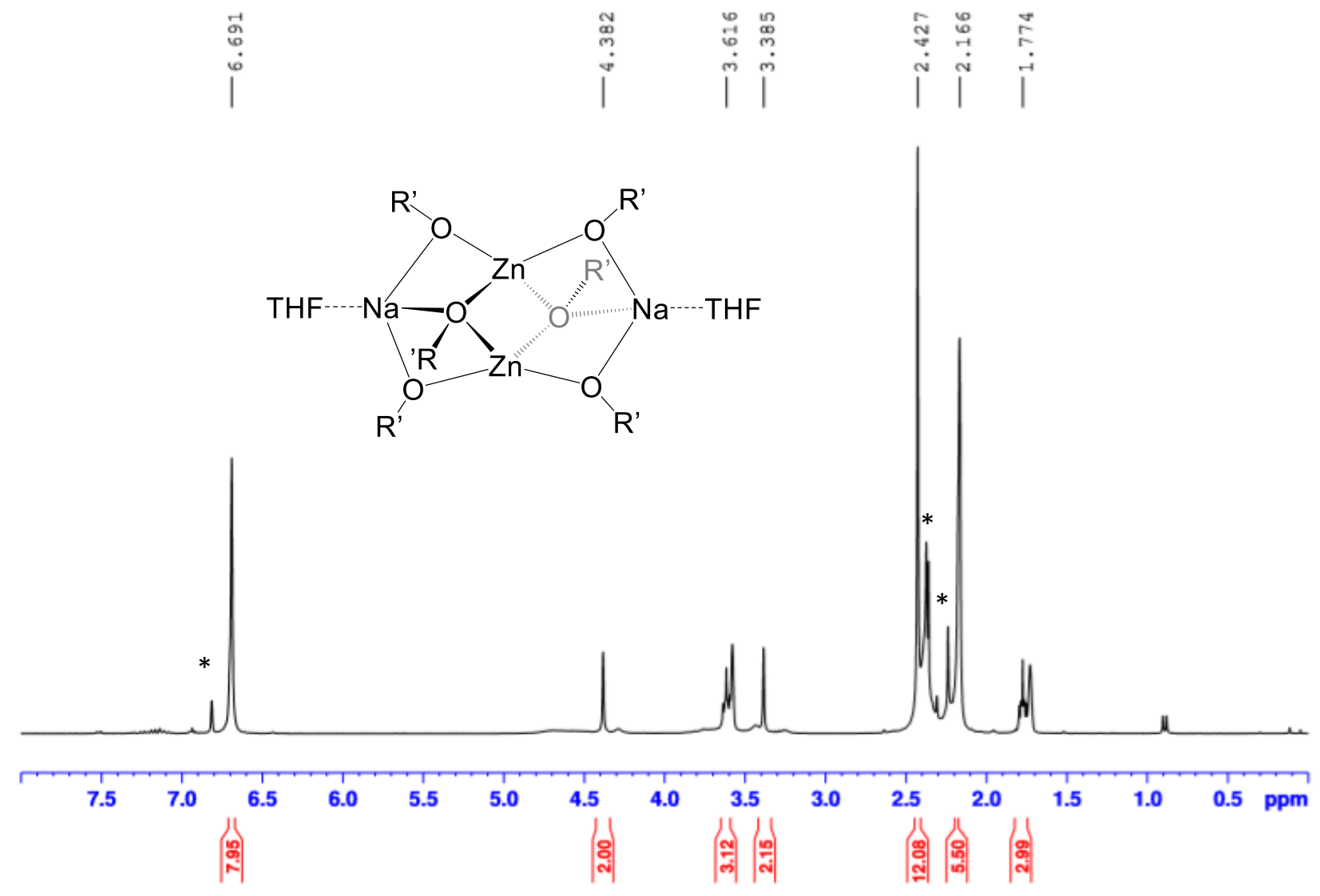

Figure S15: ${ }^{1} \mathrm{H}-\mathrm{NMR}$ spectrum of 9 in $\mathrm{D}_{8}$-THF(*): resonances of residual amounts of ketone 7, probably due to partial hydrolysis of 9) 


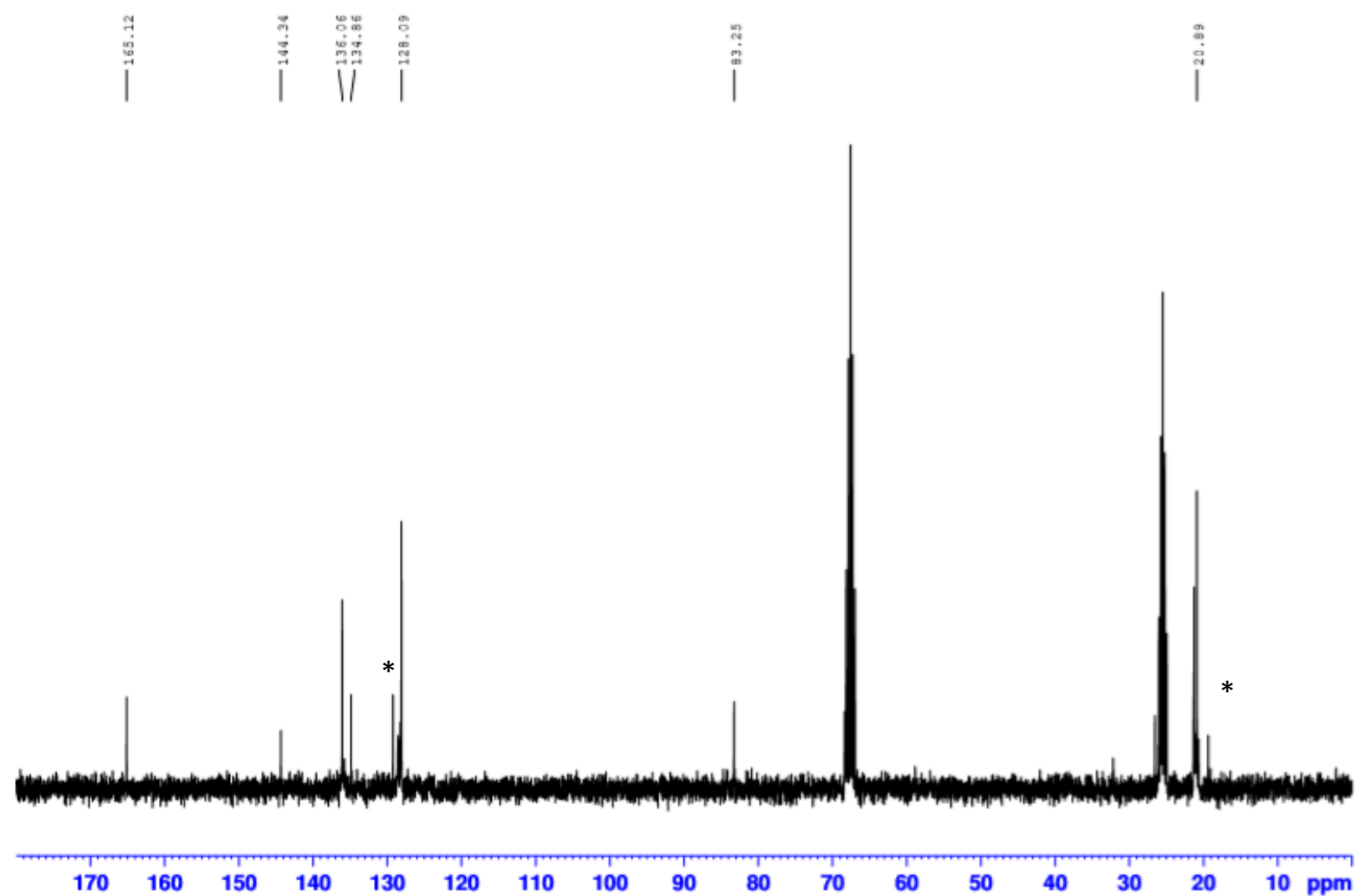

Figure S16: ${ }^{13} \mathrm{C}\left\{{ }^{1} \mathrm{H}\right\}-\mathrm{NMR}$ spectrum of 9 in $\mathrm{D}_{8}$-THF $\left({ }^{*}\right.$ : resonance of residual resonances of residual amounts of ketone 7, probably due to partial hydrolysis of 9)

${ }^{1} \mathrm{H}-\mathrm{NMR}$ monitoring of reaction of 6 with variable amount of $2^{\prime}, 4^{\prime}, 6^{\prime}$-trimethylacetophenone (7)

When 6 (41.5 mg, $0.05 \mathrm{mmol})$ is reacted with one molar equivalent of $7(7.8 \mu \mathrm{L}, 0.05 \mathrm{mmol})$ in $0.5 \mathrm{~mL}$ of $\mathrm{D}_{8}$ THF only compound 9 is detected along with 1 and HMDS(H) (see figure S17) in almost 33\% conversion along with unreacted $\mathbf{6}$. When the reaction was carried out with 3 equivalents of $\mathbf{7}$ ( $23.4 \mu \mathrm{L}, 0.15 \mathrm{mmol}$ ) only $\mathbf{9}, \mathbf{1}$ and $\operatorname{HMDS}(\mathrm{H})$ were observed.

Signals for $1(*)$, signals for $\mathbf{6}\left({ }^{*}\right)$, signals for $9\left({ }^{*}\right)$, signal for $\operatorname{HMDS}(H)(*)$, signals for $\mathbf{7}\left({ }^{*}\right)$ 


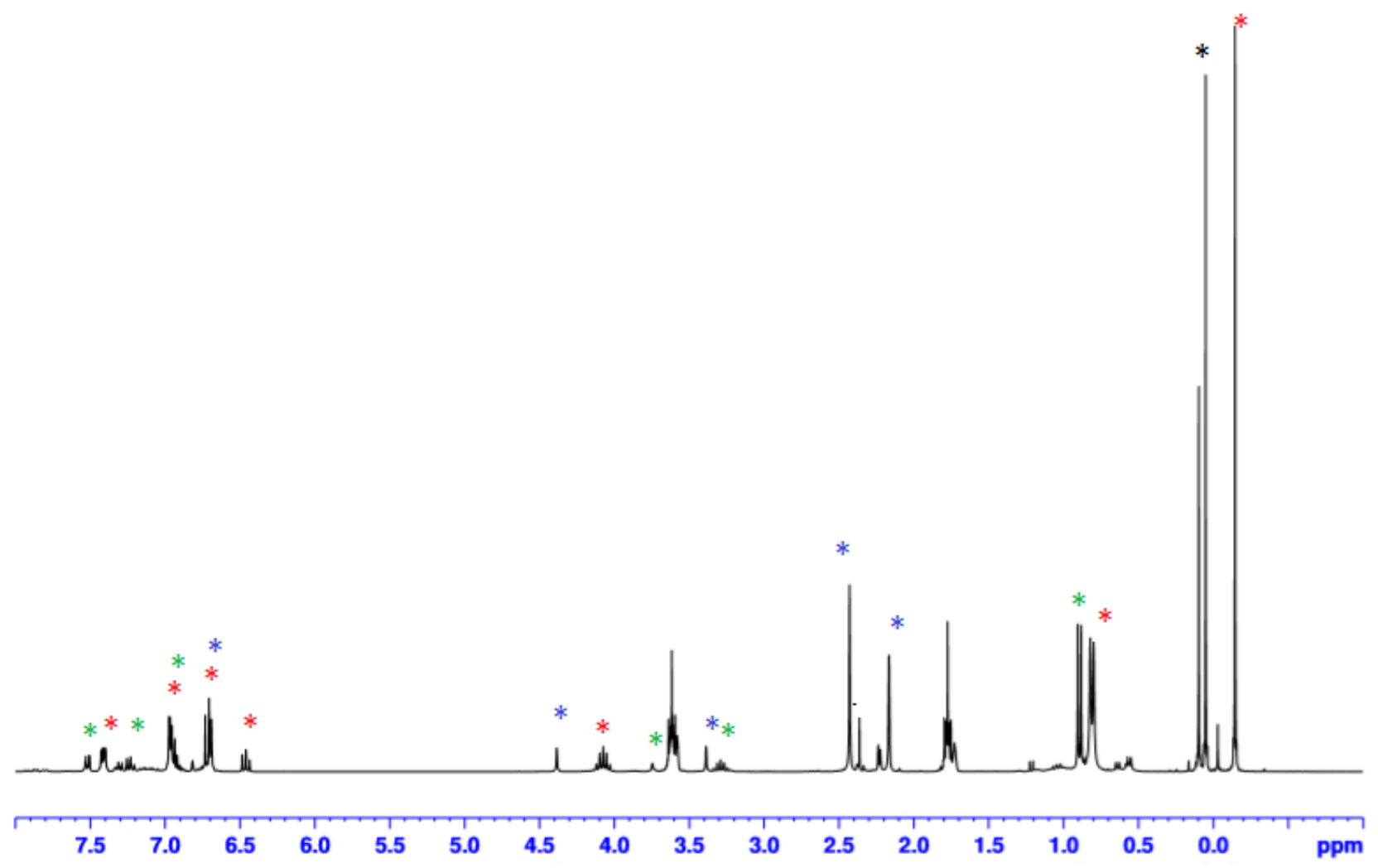

Figure S17: ${ }^{1} \mathrm{H}-\mathrm{NMR}$ spectrum in $\mathrm{D}_{8}$-THF of 6 with 1eq. of 7 , after $1 \mathrm{~h}$ heating

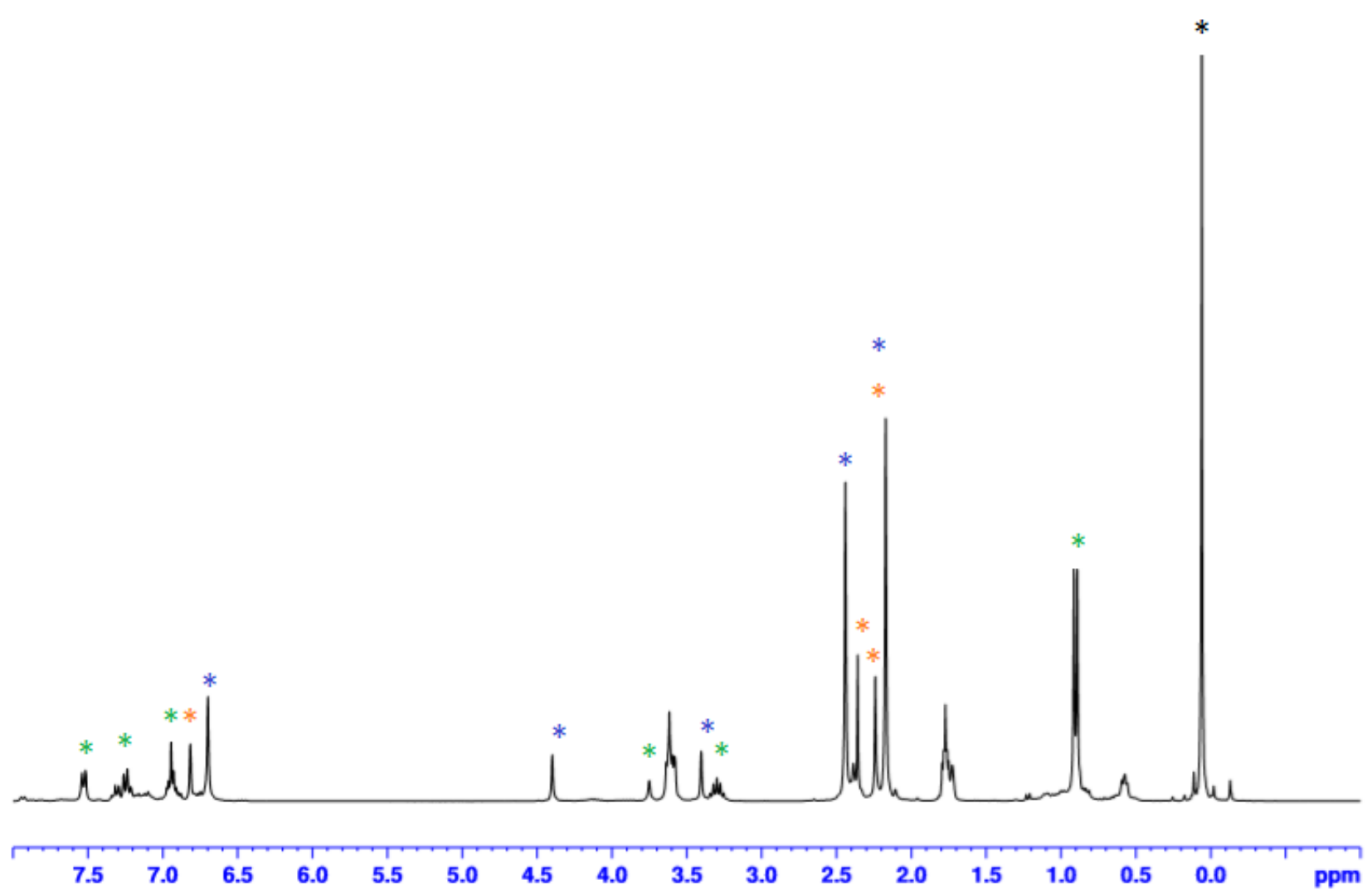

Figure S18: ${ }^{1} \mathrm{H}-\mathrm{NMR}$ spectrum in $\mathrm{D}_{8}$-THF of 6 with 3eq. of 7, after $1 \mathrm{~h}$ heating 


\section{Synthesis of $\left[\left\{\mathrm{Na}\left(\mathrm{OC}\left(=\mathrm{CH}_{2}\right) \mathrm{Mes}\right) \mathrm{THF}\right\}_{4}\right](10)$}

$0.17 \mathrm{~mL}$ ( $1 \mathrm{mmol}$ ) of 7 were added to a solution of $580 \mathrm{mg}$ (1mmol) of freshly prepared [(TMDEA $\left.)_{2} \mathrm{NaZn}\left(\mathrm{CH}_{2} \mathrm{SiMe}_{3}\right)_{3}\right](4){ }^{9}$ and $5 \mathrm{~mL}$ of THF. The colourless solution obtained was allowed to stir for $1 \mathrm{~h}$ at room temperature. The reaction mixture was allowed to stir for $1 \mathrm{~h}$ at room temperature, then volatiles were removed under vacuum. $2 \mathrm{~mL}$ of fresh hexane were added to the white solid residue, the resulting suspension was gently heated, affording a colourless solution. Overnight storage in a fridge $\left(4^{\circ} \mathrm{C}\right)$ furnished colourless crystal of $\left[\left\{\mathrm{Na}\left(\mathrm{OC}\left(=\mathrm{CH}_{2}\right) \mathrm{Mes}\right) \mathrm{THF}\right\}_{4}\right](\mathbf{1 0})(40 \mathrm{mg}, 15 \%)$ When the reaction was monitored by ${ }^{1} \mathrm{H}-$ NMR quantitative conversion of 6 into 9 was observed (figure S21).

${ }^{1} \mathrm{H}-\mathrm{NMR}\left(\mathrm{C}_{6} \mathrm{D}_{6} ; 298 \mathrm{~K} ; 300 \mathrm{MHz}\right) \delta(\mathrm{ppm}): 6.85[\mathrm{~s}, 8 \mathrm{H}, \mathrm{Mes}], 4.06[\mathrm{~s}, 4 \mathrm{H}, \mathrm{CH}=\mathrm{CHH}], 3.71\left[\mathrm{~s}, 4 \mathrm{H}, \mathrm{CH}=\mathrm{CH} H^{\prime}\right]$ $3.46\left[\mathrm{~s}, 16 \mathrm{H}, \mathrm{OCH}_{2} \mathrm{THF}\right] 2.54\left[\mathrm{~s}, 24 \mathrm{H}, \mathrm{CH}_{3} \mathrm{Mes}\right], 2.20\left[\mathrm{~s}, 12 \mathrm{H}, \mathrm{CH}_{3} \mathrm{Mes}\right], 1.36\left[\mathrm{~s}, 16 \mathrm{H}, \mathrm{CH}_{2} \mathrm{THF}\right]{ }^{13} \mathrm{C}\left\{{ }^{1} \mathrm{H}\right\}-\mathrm{NMR}$ $\left(\mathrm{C}_{6} \mathrm{D}_{6} ; 298 \mathrm{~K} ; 75 \mathrm{MHz}\right) \delta$ (ppm): 170.2 [C-O] 144.8, 134.5, 134.1 [ $\mathrm{C}_{\text {quaternary }} \mathrm{Mes}$ ] 128.2 [CH Mes], 78.1 [=CHH'], $68.0\left[\mathrm{OCH}_{2} \mathrm{THF}\right], 21.0$ [ $\left.\mathrm{CH}_{3} \mathrm{Mes}\right], 20.5\left[\mathrm{CH}_{3} \mathrm{Mes}\right]$

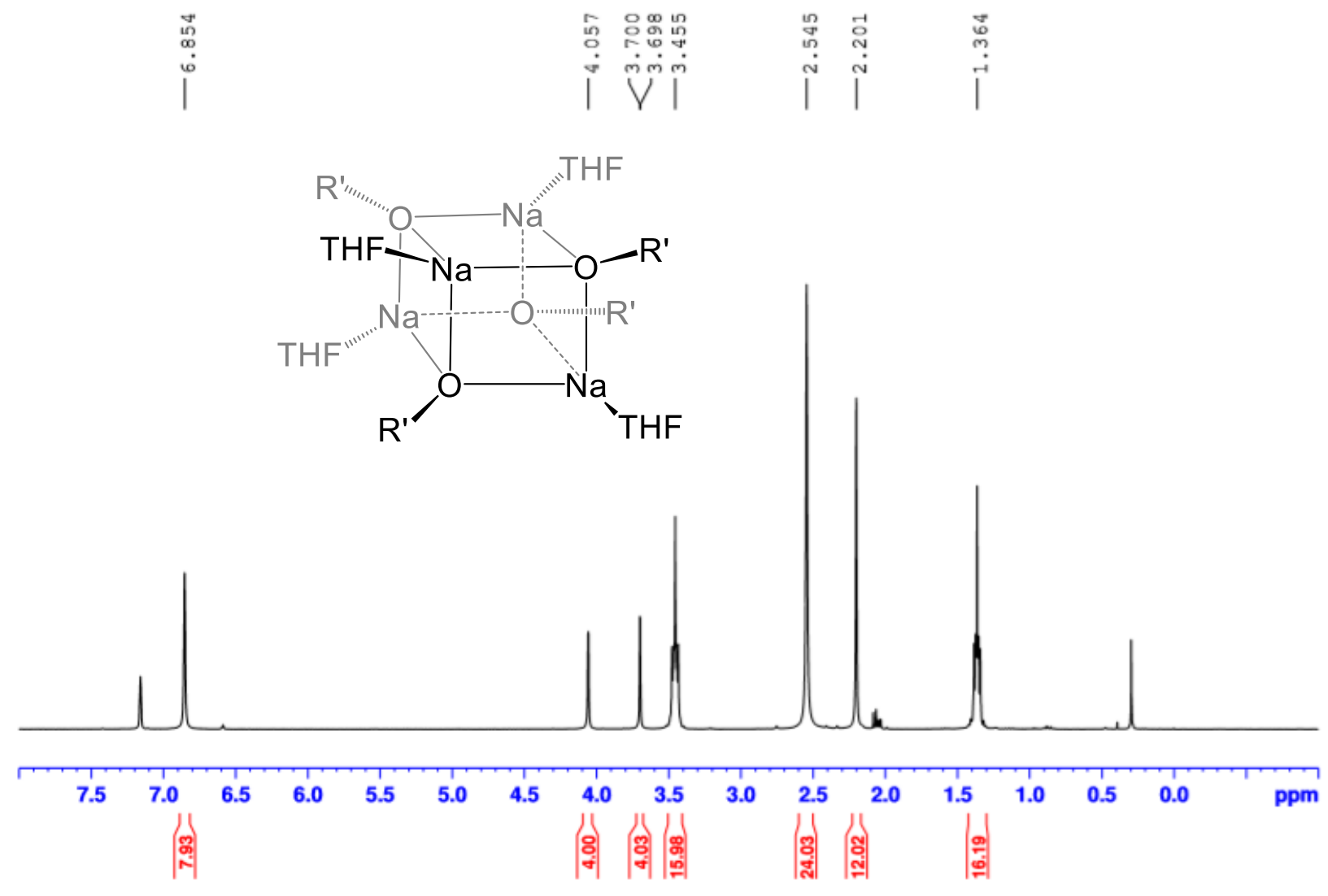

Figure S19: ${ }^{1} \mathrm{H}-\mathrm{NMR}$ spectrum of 10 in $\mathrm{C}_{6} \mathrm{D}_{6}$ 


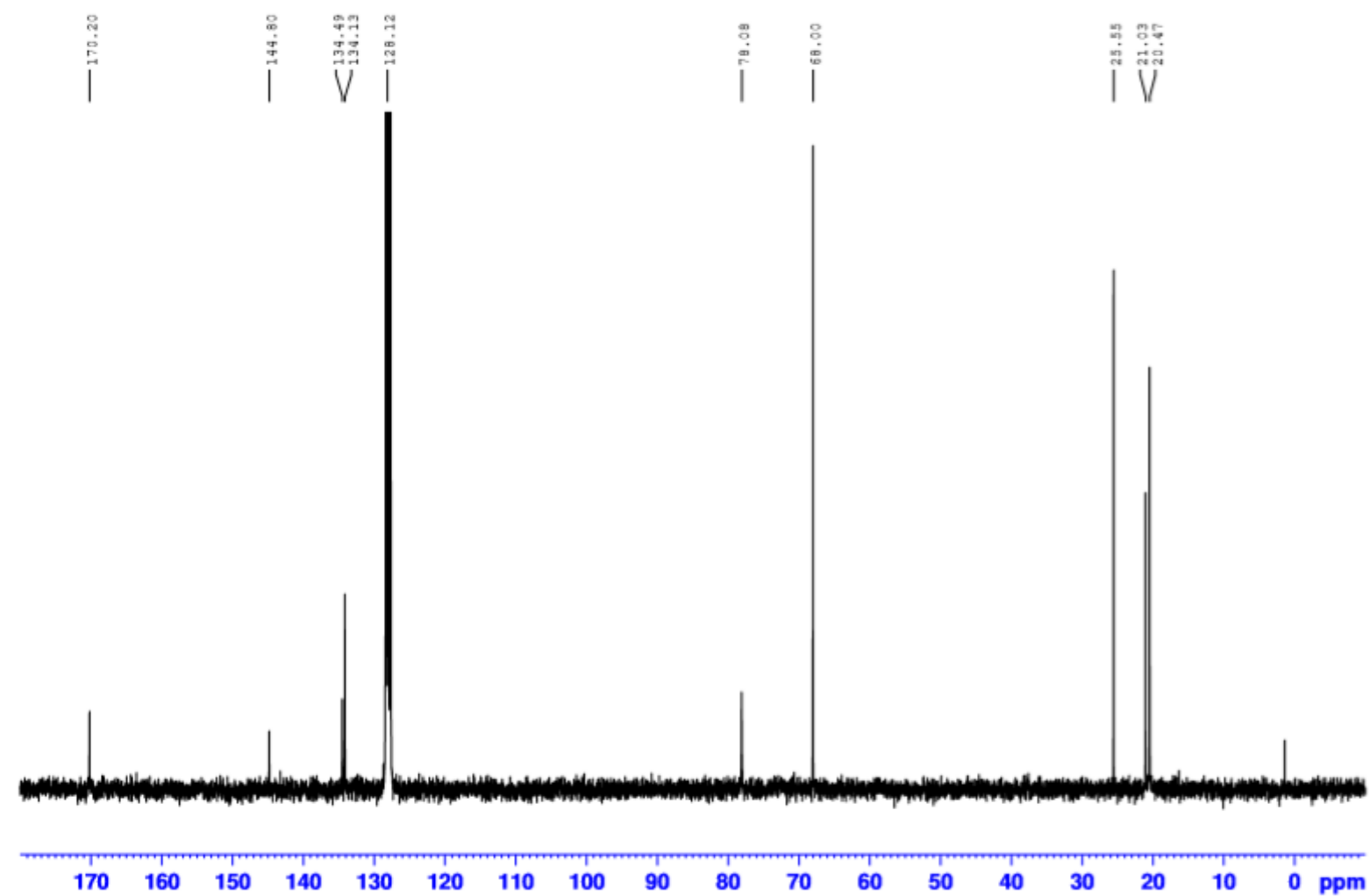

Figure S20: ${ }^{13} \mathrm{C}\left\{{ }^{1} \mathrm{H}\right\}-\mathrm{NMR}$ spectrum of 10 in $\mathrm{C}_{6} \mathrm{D}_{6}$

\section{${ }^{1} \mathrm{H}-\mathrm{NMR}$ monitoring of 4 with variable amount of $2^{\prime}, 4^{\prime}, 6^{\prime}$ trimethylacetophenone (7)}

When 4 ( $58 \mathrm{mg}, 0.1 \mathrm{mmol}$ ) was reacted with with 2 equivalents of 7 ( $32 \mu \mathrm{L}, 0.2 \mathrm{mmol}$ ) in $0.5 \mathrm{~mL}$ of $\mathrm{D}_{8}$-THF, afforded $\mathbf{1 0}$ in the same yields as when only one equivalent of $\mathbf{7}$ was employed (figure S22).

Signals for $10(*)$, signals for $\mathbf{7}\left({ }^{*}\right)$, signals for $\mathrm{Zn}\left(\mathrm{CH}_{2} \mathrm{SiMe}_{3}\right)_{2}\left({ }^{*}\right)$ and TMEDA $\left({ }^{*}\right)$ 


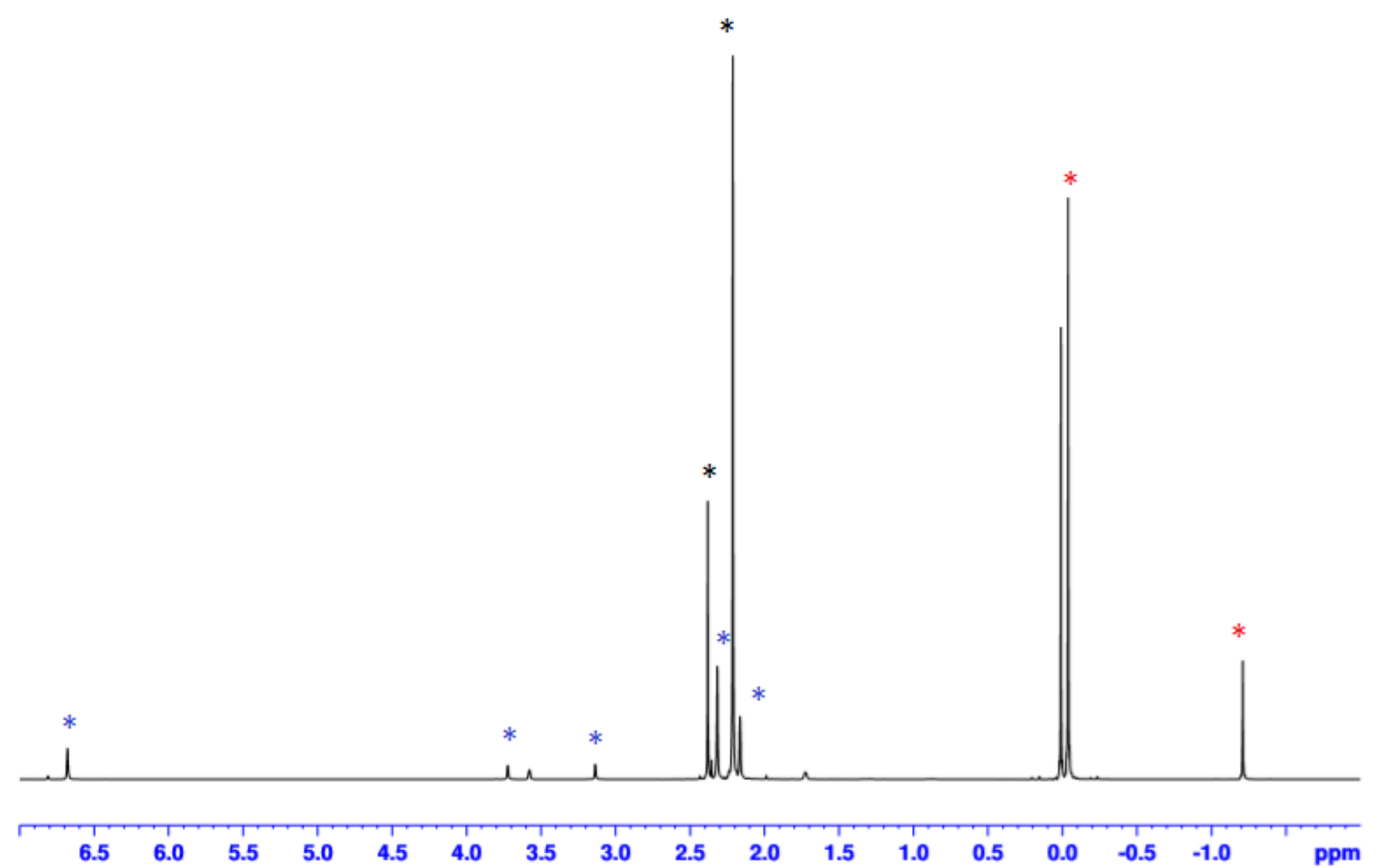

Figure S21: ${ }^{1} \mathrm{H}-\mathrm{NMR}$ spectrum in $\mathrm{D}_{8}$-THF of 4 with 1eq. of 7, after 5 min.

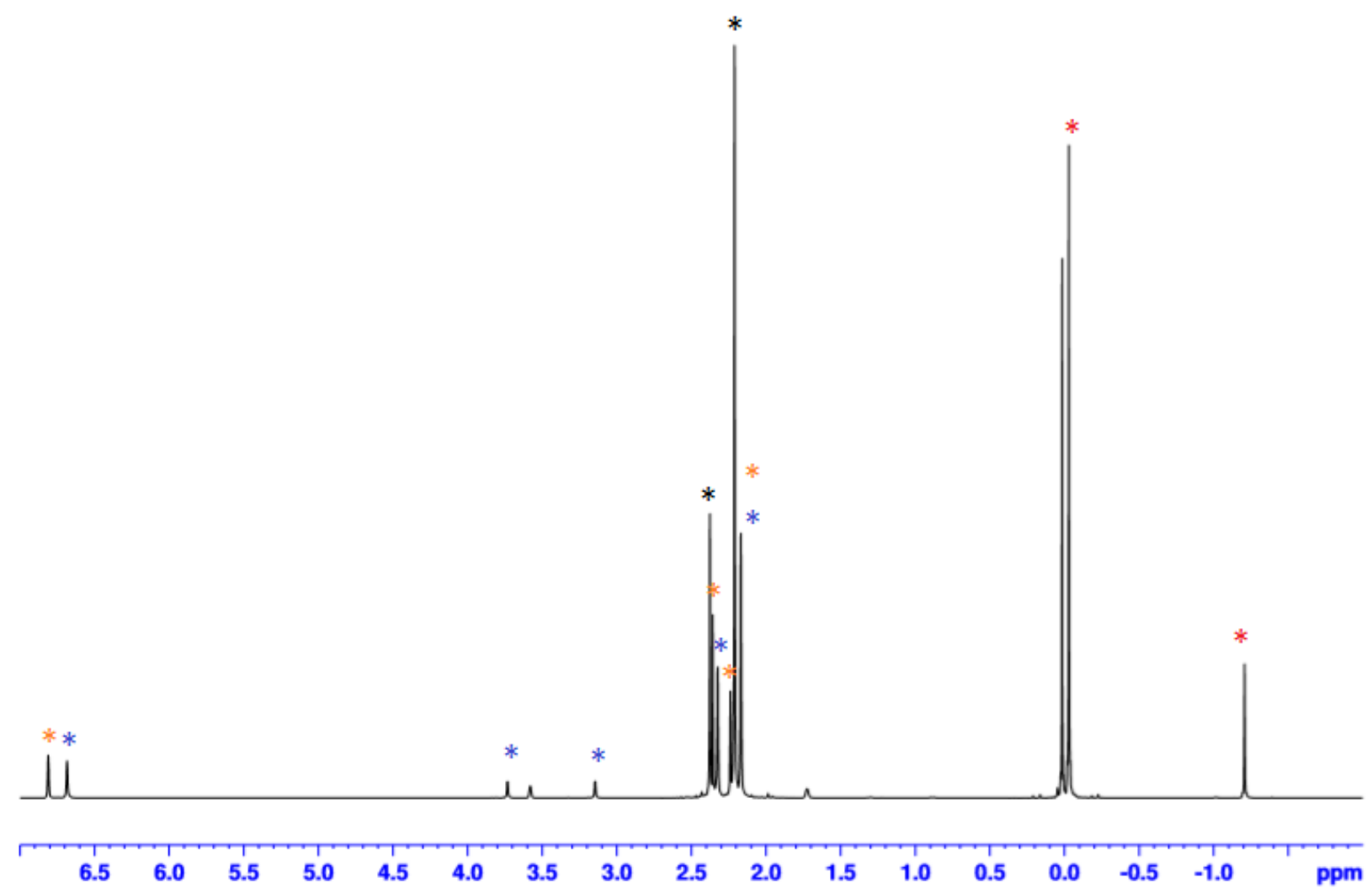

Figure S22: ${ }^{1} \mathrm{H}-\mathrm{NMR}$ spectrum in $\mathrm{D}_{8}$-THF of 4 with 2eq. of 7 , after 5 min. 


\section{Synthesis of $\left[\left\{\left(\mathrm{Ph}_{2} \mathrm{Si}\left(\mathrm{NAr}^{*}\right)_{2}\right) \mathrm{Mg}\left(\mathrm{CH}_{2} \mathrm{SiMe}_{3}\right)(\mathrm{THF})\right\}^{-}\left\{\mathrm{Na}(\mathrm{THF})_{6}\right\}^{+}\right](11)$}

$220 \mathrm{mg}$ of $\mathrm{NaCH}_{2} \mathrm{SiMe}_{3}(2 \mathrm{mmol})$ and $400 \mathrm{mg}$ of $\mathrm{Mg}\left(\mathrm{CH}_{2} \mathrm{SiMe}_{3}\right)_{2}$ were suspended in $10 \mathrm{~mL}$ of hexane and allowed to stir for 10' at room temperature. Then $1060 \mathrm{mg}$ ( $2 \mathrm{mmol}$ ) of 1 were added and the white suspension was allowed to stir for $1 \mathrm{~h} .4 \mathrm{~mL}$ of THF were dripped in the suspension and the mixture was gently heated in order to obtain a pale yellow solution. Overnight storage in a freezer $\left(-33^{\circ} \mathrm{C}\right)$ furnished colourless crystal of 11 (1612 mg; 78\%)

${ }^{1} \mathrm{H}-\mathrm{NMR}\left(\mathrm{C}_{6} \mathrm{D}_{6} ; 298 \mathrm{~K} ; 400 \mathrm{MHz}\right) \delta$ (ppm): 7.89 [d, 4H, Ph], 7.11 [dd, 4H, Ph], $7.02[\mathrm{~d}, 2 \mathrm{H}, \mathrm{Ph}], 6.98$ [d, 4H, $\left.\mathrm{Ar}^{*}\right], 6.64\left[\mathrm{t}, 2 \mathrm{H}, \mathrm{Ar}^{*}\right], 4.22[\mathrm{~s}, 4 \mathrm{H}, \mathrm{CH}, \mathrm{iPr}], 3.47\left[\mathrm{t}, 28 \mathrm{H}, \mathrm{O}-\mathrm{CH}_{2}, \mathrm{THF}\right], 1.36\left[\mathrm{~m}, 28 \mathrm{H}, \mathrm{CH}_{2}, \mathrm{THF}\right], 1.15$ [d, 24H, $\mathrm{CH}_{3}$, iPr], $0.34\left[\mathrm{~s}, 9 \mathrm{H}, \mathrm{CH}_{3}-\mathrm{CH}_{2} \mathrm{SiMe}_{3}\right],-1.28\left[\mathrm{~s}, 2 \mathrm{H}, \mathrm{CH}_{2},-\mathrm{CH}_{2} \mathrm{SiMe}_{3}\right] .{ }^{13} \mathrm{C}\left\{{ }^{1} \mathrm{H}\right\}-\mathrm{NMR}\left(\mathrm{C}_{6} \mathrm{D}_{6} ; 298 \mathrm{~K} ; 100 \mathrm{MHz}\right) \delta$ (ppm):153.91, 146.13, 143.21 [C quarternary, $\mathrm{Ph}$ or $\left.\mathrm{Ar}^{*}\right], 135.11$ [CH, Ph], $126.21[\mathrm{CH}, \mathrm{Ph}], 126.14$ [CH, Ph], $122.94\left[\mathrm{CH}, \mathrm{Ar}^{*}\right], 115.25[\mathrm{CH}, \mathrm{Ar} *], 68.20\left[\mathrm{O}-\mathrm{CH}_{2}, \mathrm{THF}\right], 28.94\left[\mathrm{CH}, \mathrm{iPr}, \mathrm{Ar}{ }^{*}\right], 25.41\left[\mathrm{CH}_{2}, \mathrm{THF}\right], 25.26\left[\mathrm{CH}_{3}\right.$, iPr, Ar*], $4.73\left[\mathrm{CH}_{3},-\mathrm{CH}_{2} \mathrm{SiMe}_{3}\right],-0.82\left[\mathrm{CH}_{2},-\mathrm{CH}_{2} \mathrm{SiMe}_{3}\right]$.
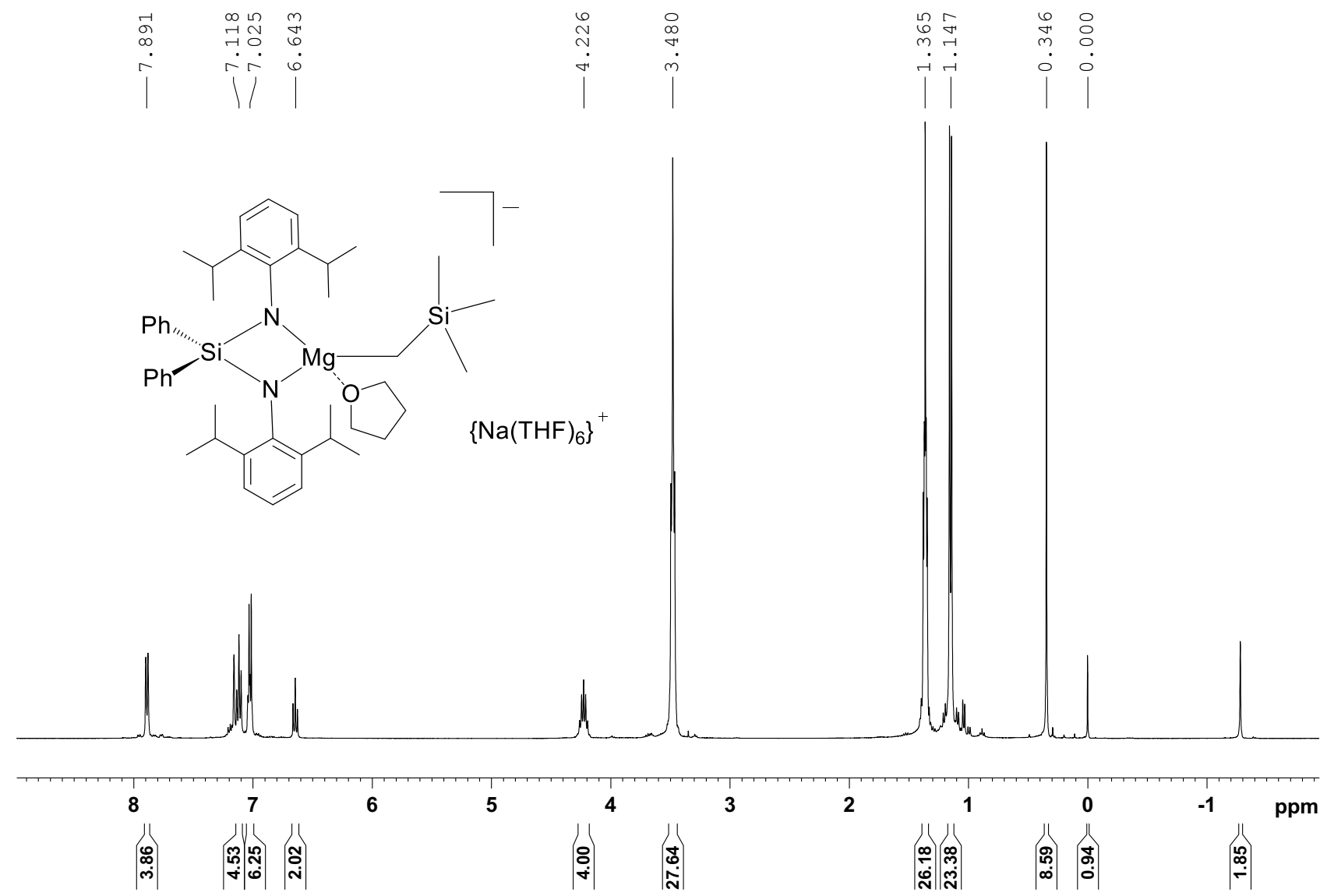

Figure S23: ${ }^{1} \mathrm{H}-\mathrm{NMR}$ spectrum of 11 in $\mathrm{C}_{6} \mathrm{D}_{6}$ 


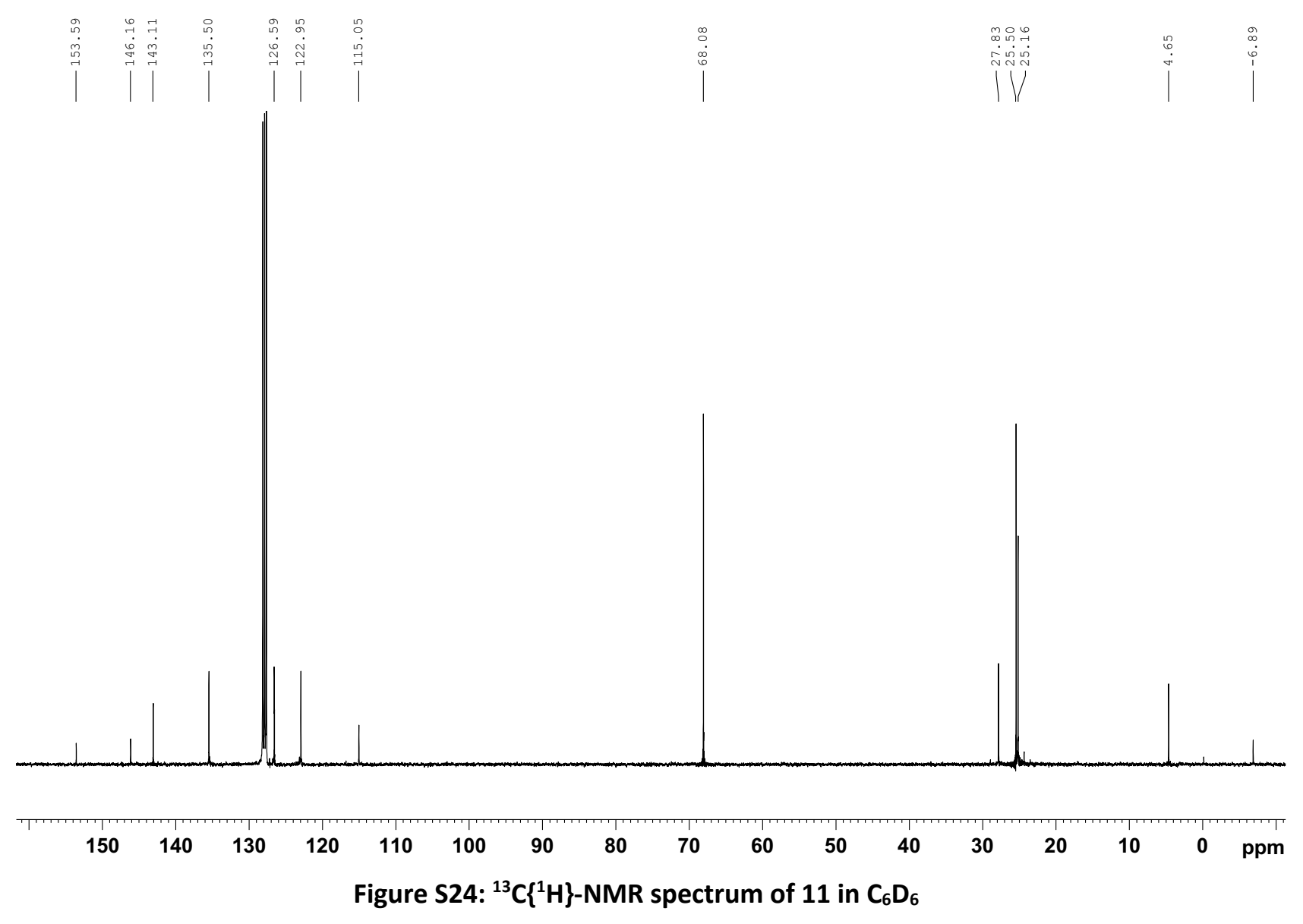

\section{Synthesis of $\left[\left\{\left(\mathrm{Ph}_{2} \mathrm{Si}(\mathrm{NAr} *)_{2}\right) \mathrm{Mg}\left(\mathrm{OC}\left(=\mathrm{CH}_{2}\right) \mathrm{Mes}\right)(\mathrm{THF})\right\}^{-}\left\{\mathrm{Na}(\mathrm{THF})_{5}\right\}^{+}\right](12)$}

$516 \mathrm{mg}$ of $11(0.5 \mathrm{mmol})$ were solubilized in $3 \mathrm{~mL}$ of THF. The solution was placed in a cold bath at $-40^{\circ} \mathrm{C}$ and $0.08 \mathrm{~mL}$ of $7(0.5 \mathrm{mmol})$ was added. The solution was stirred for $30^{\prime}$ and then the mixture was alloed to warm up to room temperature and then it was stirred for an additional hour. Volatiles were removed under vacuum. The white residue was solubilized with $3 \mathrm{~mL}$ of hexane, $0.5 \mathrm{~mL}$ of THF and a gently heating.

Overnight storage in a fridge $\left(4^{\circ} \mathrm{C}\right)$ furnished colourless crystal of 12 (160 mg; 33\%)

${ }^{1} \mathrm{H}-\mathrm{NMR}\left(\mathrm{D}_{8}\right.$-THF; 298K; $\left.300 \mathrm{MHz}\right) \delta$ (ppm):7.26 [m, 4H, Ph], 6.91 [m, 6H, Ph], 6.69 [d, 4H, Ar*, J=7.37 Hz], 6.57 [s, 2H, Mes], $6.39[\mathrm{t}, 2 \mathrm{H}, \mathrm{Ar} *, \mathrm{~J}=7.37 \mathrm{~Hz}$ ], 4.1 [sept., $4 \mathrm{H}, \mathrm{CH}$ iPr, J=6.78Hz], $3.75[\mathrm{~d}, 1 \mathrm{H},=\mathrm{CHH}$ J=1.94 $\mathrm{Hz}$ ], $3.66\left[\mathrm{~m}, 18 \mathrm{H}, \mathrm{OCH}_{2} \mathrm{THF}\right], 3.10\left[\mathrm{~d}, 1 \mathrm{H},=\mathrm{CHH}\right.$ J=1.93 Hz], $2.15\left[\mathrm{~s}, 9 \mathrm{H}, \mathrm{CH}_{3}, \mathrm{Mes}\right], 1.81\left[\mathrm{~m}, 18 \mathrm{H}, \mathrm{CH}_{2} \mathrm{THF}\right]$, 0.78 [d, 24H, CH $\mathrm{iPr} J=6.78 \mathrm{~Hz}$ ] ${ }^{13} \mathrm{C}\left\{{ }^{1} \mathrm{H}\right\}-N M R$ (D $\left.-\mathrm{THF} ; 298 \mathrm{~K} ; 75 \mathrm{MHz}\right) \delta$ (ppm): 165.5 [C-O],154.6, 145.5, 144.3, 135.7, 133.7 [ $\left.\mathrm{C}_{\text {quaternary }} \mathrm{Ph}, \mathrm{Ar}^{*}, \mathrm{Mes}\right], 136.5$ [CH Ph], 127.7 [CH Mes], 122.3, 115.6 [CH Ar*] 81.4 $\left[\mathrm{CO}=\mathrm{CHH}^{\prime}\right], 68.4\left[\mathrm{OCH}_{2} \mathrm{THF}\right], 28.3\left[\mathrm{CH}\right.$ iPr], $26.5[\mathrm{CH} \mathrm{THF}], 25.4\left[\mathrm{CH}_{3} \mathrm{iPr}\right], 21.2,20.6\left[\mathrm{CH}_{3} \mathrm{Mes}\right]$ 


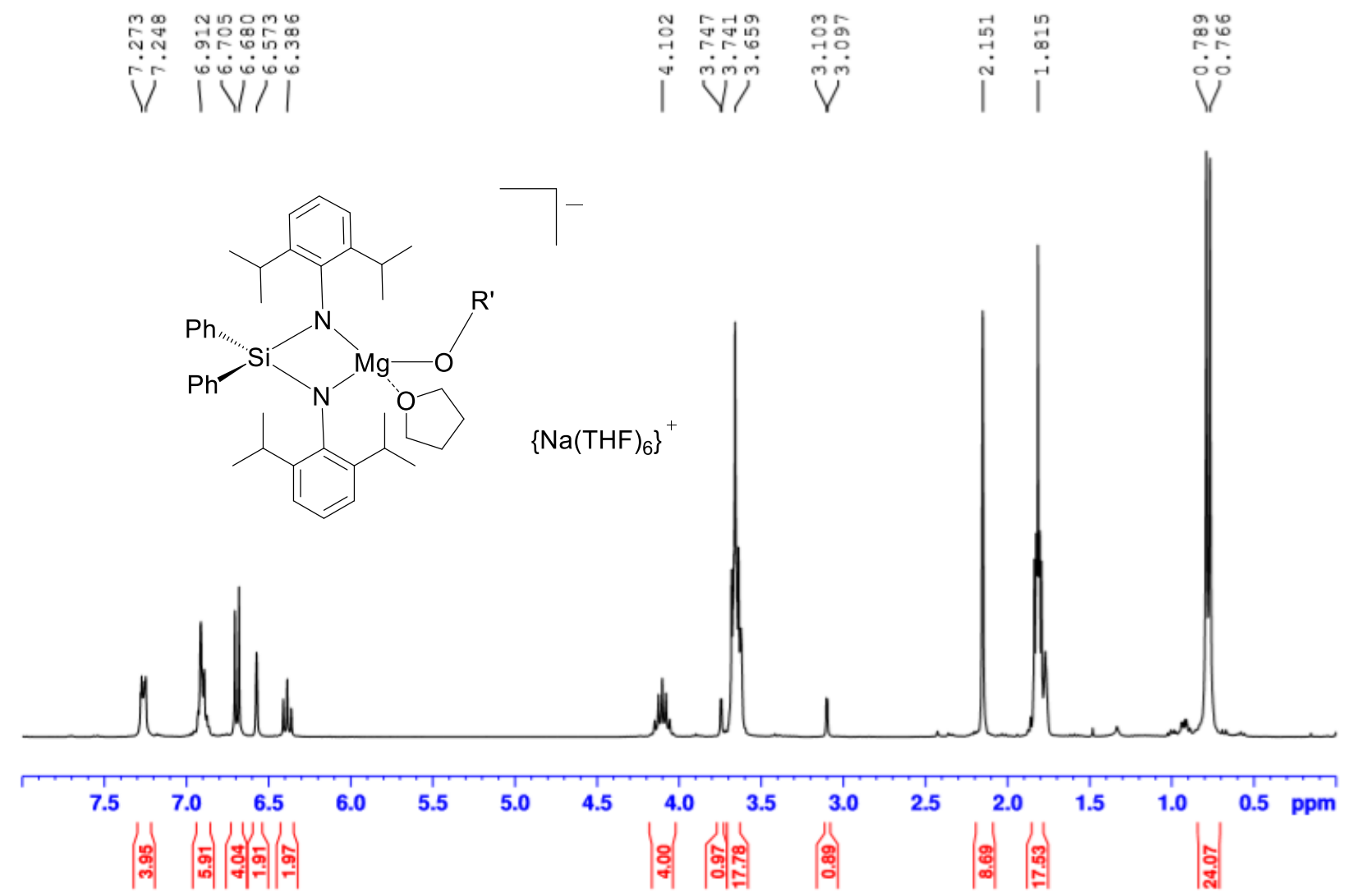

Figure S25: ${ }^{1} \mathrm{H}-\mathrm{NMR}$ spectrum of 12 in $\mathrm{D}_{8}$-THF 


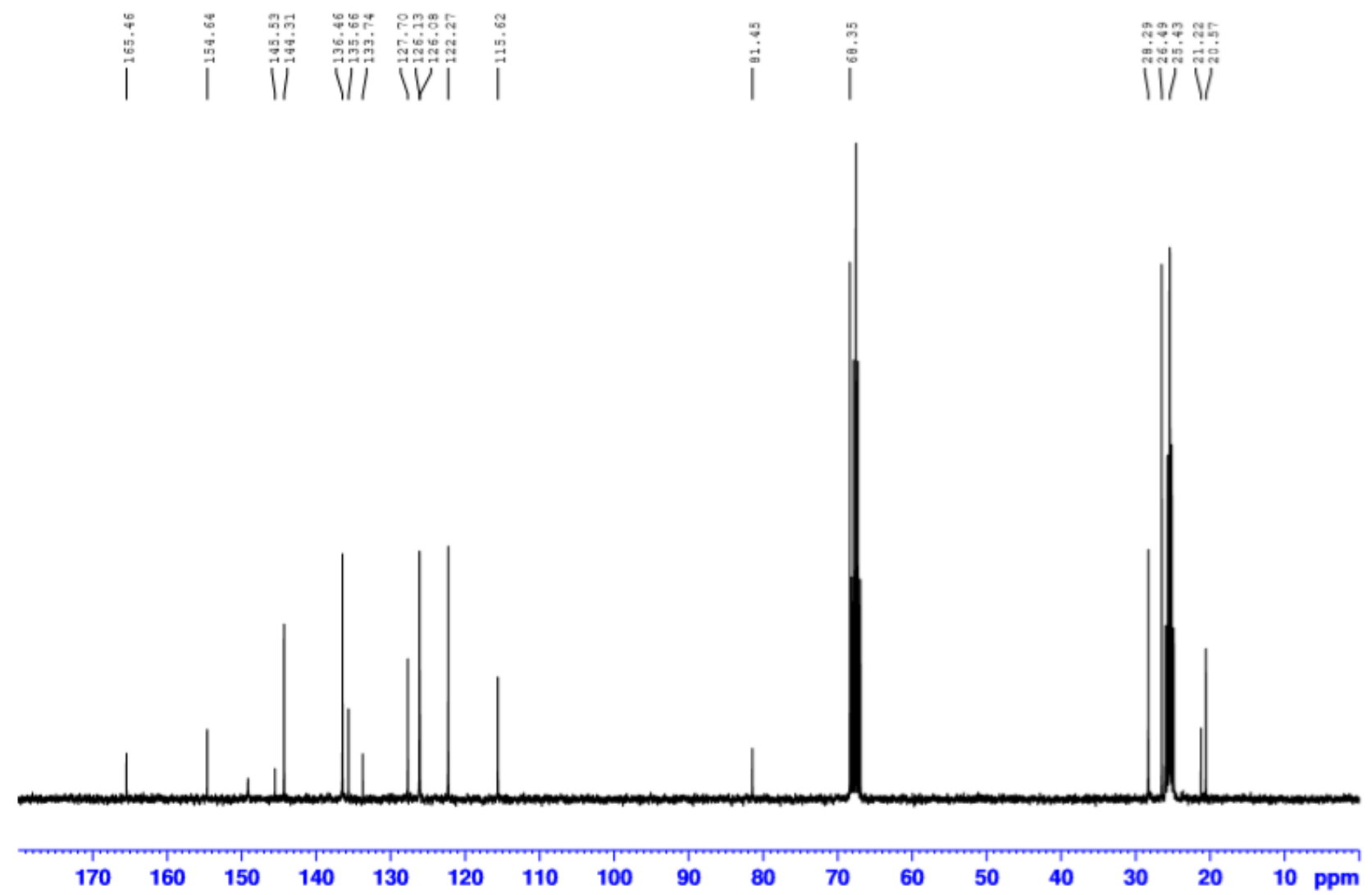

Figure S26: ${ }^{13} C\left\{{ }^{1} H\right\}-N M R$ spectrum of 12 in $D_{8}$-THF 


\section{References}

(1) Blair, V. L.; Clegg, W.; Kennedy, A. R.; Livingstone, Z.; Russo, L.; Hevia, E. Magnesium-Mediated Benzothiazole Activation: A Room-Temperature Cascade of C-H Deprotonation, C-C Coupling, Ring-Opening, and Nucleophilic Addition Reactions Angew. Chem. Int. Ed. 2011, 50, 9857-9860.

(2) Clegg, W.; Conway, B.; Kennedy, A. R.; Klett, J.; Mulvey, R. E.; Russo, L. Synthesis and Structures of [(Trimethylsilyl)methyl]sodium and -potassium with Bi- and Tridentate N-Donor Ligands Eur. J. Inorg. Chem. 2011, 5, 721-726.

(3) Sobrino, S.; Navarro, M.; Fernández-Baeza, J.; Sánchez-Barba, L. F.; Garcés, A.; Lara-Sánchez, A.; CastroOsma, J. A. Efficient $\mathrm{CO}_{2}$ fixation into cyclic carbonates catalyzed by NNO-scorpionate zinc complexes Dalton Trans., 2019, 48, 10733-10742.

(4) Yeardley, C.; Kennedy, A. R.; Gros, P. C.; Touchet, S.; Fairley, M.; McLellan, R.; Martínez-Martínez, A. J.; O'Hara, C. T. Structural and metal-halogen exchange reactivity studies of sodium magnesiate biphenolate complexes Dalton Trans. 2020, 49, 5257-5263.

(5) Armstrong, D. R.; Emerson, H. S.; Hernán-Gómez, A.; Kennedy, A. R.; Eva Hevia, E. New supramolecular assemblies in heterobimetallic chemistry: synthesis of a homologous series of unsolvated alkali-metal zincates Dalton Trans. 2014, 43, 14229-14238.

(6) Oxford Diffraction (2018). CrysAlisPro (Version 1.171.40.37a). Oxford Diffraction Ltd., Yarnton, Oxfordshire, UK.

(7) Sheldrick, G. M. SHELXT - Integrated space-group and crystal-structure determination Acta Cryst. 2015, A71, 3-8.

(8) Sheldrick, G. M. Crystal structure refinement with SHELXL (2015). Acta Cryst. 2015, C71, 3-8.

(9) Dolomanov, O. V.; Bourhis, L. J.; Gildea, R. J.; Howard, J. A. K.; Puschmann, H. OLEX2: a complete structure solution, refinement and analysis program J. Appl. Cryst. 2009 42, 339-341.

(10) D. Y. Lee, D. Y.; Hartwig, J. F. Zinc Trimethylsilylamide as a Mild Ammonia Equivalent and Base for the Amination of Aryl Halides and Triflates Org. Lett. 2005, 7, 1169-1172. 